\title{
Análise da paisagem na zona de amortecimento do Parque Nacional das Emas - Brasil
}

\author{
Analysis of the landscape in the damping zone of the Emas National Park - \\ Brazil
}

\author{
Alécio Perini Martins ', Carlos Eduardo Damasceno ", Bruno Jefferson Soares de \\ Oliveira III
}

\begin{abstract}
RESUMO
Localizado no sudoeste do Estado de Goiás, o Parque Nacional das Emas foi criado no ano de 1961 e apresenta uma área total de 132.813 ha e uma Zona de Amortecimento com 263.432 ha, que não cumpre totalmente o seu papel ecológico por estar intensamente ocupada por atividades agropecuárias. Este artigo apresenta como objetivo analisar os diferentes elementos que compõem a paisagem na Zona de Amortecimento do Parque Nacional das Emas, indicando as áreas mais vulneráveis e que necessitam de ações urgentes do poder público para a sua conservação. O estudo foi desenvolvido a partir de cartografia de síntese e utilização de geotecnologias, com suporte em pesquisa de campo. Predomina na paisagem relevo plano em chapadas ( $86 \%$ da área), recobertos principalmente por latossolos $(70,7 \%)$ e áreas de afloramento hídrico em solos hidromórficos (4,4\% da área). Atualmente, 63,7\% da Zona de Amortecimento encontra-se ocupada pelo agronegócio, apresentando fragilidade ambiental de média a alta, sendo que $70,2 \%$ da área encontra-se apta à agricultura com problemas simples de conservação e 17,4\% encontra-se apta à agricultura com problemas complexos de conservação, sobretudo correção de solos e criação de mecanismos para prevenção e/ou contenção de processos erosivos. Cerca de $25 \%$ da área ainda apresenta vegetação natural conservada.
\end{abstract}

Palavras-chave: Fragilidade Ambiental; Paisagem; Unidade de Conservação; Uso e ocupação da terra.

\section{ABSTRACT}

Located in the southwest of the state of Goiás, Brazil, the Emas National Park was created in 1961 and has a total area of 132,813 ha and a damping zone with 263,432 ha, that does not fulfil its ecological role because it is intensely occupied by agricultural activities. This article aims to analyze the different elements that compose the landscape in the damping zone of the National Park of Emas, indicating the most vulnerable areas and needing urgent actions of government institutions for its conservation. The study was developed from synthesis cartography and use of geotechnologies, with support in field research. In the landscape, plane relief predominates in plateaus ( $86 \%$ of the area), covered mainly by latosols $(70.7 \%)$ and areas of water outcrop in hydromorphic soils (4.4\% of the area). Currently, $63,7 \%$ of the damping zone is occupied by agribusiness, presenting environmental fragility of medium to high, being that $70.2 \%$ of the area is suitable for agriculture with simple conservation problems and $17.4 \%$ is suitable for agriculture with complex

Doutor (2015), Mestre (2009), Licenciado e Bacharel (2007) em Geografia pelo Instituto de Geografia da Universidade Federal de Uberlândia. E-mail. alecioperini@yahoo.com.br ORCID: https://orcid.org/0000-0002-4485-0336

" Graduando em Bacharelado no curso de Geografia pela Universidade Federal de Goiás. E-mail. eduardo.geo@outlook.com.br ORCID: https://orcid.org/0000-0003-3914-1102

I'I Graduando em Bacharelado no curso de Geografia pela Universidade Federal de Goiás. É bolsista de Iniciação Científica do CNPq. Email. jefbrunojeffersoms.o@gmail.com ORCID https://orcid.org/0000-0002-2412-3983 
conservation problems, especially soil correction and creation of mechanisms for prevention and/or containment erosive processes. About $25 \%$ of the area still has preserved natural vegetation.

Keywords: Conservation Unit; Environmental fragility; Landscape; Land use

\section{RESUMO}

Localizado no sudoeste do Estado de Goiás, o Parque Nacional das Emas foi criado no ano de 1961 e apresenta uma área total de 132.813 ha e uma Zona de Amortecimento com 263.432 ha, que não cumpre totalmente o seu papel ecológico por estar intensamente ocupada por atividades agropecuárias. Este artigo apresenta como objetivo analisar os diferentes elementos que compõem a paisagem na Zona de Amortecimento do Parque Nacional das Emas, indicando as áreas mais vulneráveis e que necessitam de ações urgentes do poder público para a sua conservação. O estudo foi desenvolvido a partir de cartografia de síntese e utilização de geotecnologias, com suporte em pesquisa de campo. Predomina na paisagem relevo plano em chapadas ( $86 \%$ da área), recobertos principalmente por latossolos $(70,7 \%)$ e áreas de afloramento hídrico em solos hidromórficos (4,4\% da área). Atualmente, 63,7\% da Zona de Amortecimento encontra-se ocupada pelo agronegócio, apresentando fragilidade ambiental de média a alta, sendo que $70,2 \%$ da área encontra-se apta à agricultura com problemas simples de conservação e 17,4\% encontra-se apta à agricultura com problemas complexos de conservação, sobretudo correção de solos e criação de mecanismos para prevenção e/ou contenção de processos erosivos. Cerca de $25 \%$ da área ainda apresenta vegetação natural conservada.

Palavras-chave: Fragilidade Ambiental; Paisagem; Unidade de Conservação; Uso e ocupação da terra.

\section{ABSTRACT}

Located in the southwest of the state of Goiás, Brazil, the Emas National Park was created in 1961 and has a total area of 132,813 ha and a damping zone with 263,432 ha, that does not fulfil its ecological role because it is intensely occupied by agricultural activities. This article aims to analyze the different elements that compose the landscape in the damping zone of the National Park of Emas, indicating the most vulnerable areas and needing urgent actions of government institutions for its conservation. The study was developed from synthesis cartography and use of geotechnologies, with support in field research. In the landscape, plane relief predominates in plateaus ( $86 \%$ of the area), covered mainly by latosols $(70.7 \%)$ and areas of water outcrop in hydromorphic soils (4.4\% of the area). Currently, $63,7 \%$ of the damping zone is occupied by agribusiness, presenting environmental fragility of medium to high, being that $70.2 \%$ of the area is suitable for agriculture with simple conservation problems and $17.4 \%$ is suitable for agriculture with complex conservation problems, especially soil correction and creation of mechanisms for prevention and/or containment erosive processes. About $25 \%$ of the area still has preserved natural vegetation.

Keywords: Conservation Unit; Environmental fragility; Landscape; Land use.

\section{INTRODUÇÃO}

No Brasil, as Unidades de Conservação (UC's) apresentam-se como alternativas para a conservação da biodiversidade e uso sustentável dos recursos naturais. São definidas como espaços com características naturais relevantes, envolvendo em sua implantação e gestão as três esferas do governo e participação popular. No Estado de 
Goiás, as UC's ainda não são suficientes para a efetiva conservação das diferentes fitofisionomias do Cerrado, como por exemplo o Parque Nacional das Emas, que se apresenta como uma "ilha" em meio a grandes áreas de agricultura e pastagem no sudoeste do Estado (SANTOS, 2018).

A primeira legislação ambiental brasileira que apresenta conceitos, objetivos e instrumentos claros para a defesa do meio ambiente entra em vigor apenas em agosto de 1981, representada pela Política Nacional do Meio Ambiente (Lei 6.938/1981), embora grande parte dos Parques Nacionais do país tenham sido criados entre as décadas de 1940 e 1970. Anteriormente à Política Nacional do Meio Ambiente, o Código Florestal Brasileiro, promulgado em 1965 (em substituição ao decreto 23.793 de 23 de janeiro de 1934), era a única legislação nacional que estabelecia diretrizes para a conservação do meio ambiente (Lei 4771/1965), vigorando até a publicação da Lei Federal 12.651 de 25 de maio de 2012 (Novo Código Florestal Brasileiro).

A Política Nacional do Meio ambiente prevê, em seu artigo 90, a criação de espaços territoriais especialmente protegidos pelo Poder Público, viabilizando a criação do Sistema Nacional de Unidades de Conservação (SNUC) no ano de 2000 (Lei 9985/2000), estabelecendo critérios para criação e gestão de Unidades de Conservação no Brasil. No Estado de Goiás, o Sistema Estadual de Unidades de Conservação (SEUC) entrou em vigor no ano de 2002 (Lei 14247/2002), estabelecendo normas para a criação, implantação e gestão de UC's, além de dispor sobre incentivos aos municípios que possuam ou venham a criar e implantar UC's e penalizar àqueles que causem danos à fauna e à flora.

O SNUC (2000) divide os tipos de Unidades de Conservação em dois grandes grupos, sendo as Unidades de Proteção Integral, nas quais se enquadram os Parques Nacionais, visando a preservação integral da natureza, e as Unidades de Uso Sustentável, com objetivo de compatibilizar a conservação da natureza com o uso sustentável de parcela dos seus recursos naturais. Neste último grupo, se enquadram unidades como as Áreas de Proteção Ambiental (APA's), Áreas de Relevante Interesse Ecológico (ARIE) e as Reservas Particulares do Patrimônio Natural (RPPN's), que têm 
se mostrado como alternativas importantes para Zonas de Amortecimento dos Parques Nacionais, garantindo a conectividade destas com outras áreas de vegetação natural ainda conservadas.

De acordo com Santos (2018), no Sul do Estado de Goiás existem 12 Unidades de Conservação, sendo um único Parque Nacional (Parque Nacional das Emas), 3 Parques Estaduais, 1 Parque Municipal, 1 APA, 1 Floresta Nacional e 5 RPPN's, totalizando uma área de 149.981 ha, das quais o Parque Nacional das Emas responde por $88,5 \%$ do total, sendo uma das maiores Unidades de Conservação do Cerrado Brasileiro.

Localizado no extremo sudoeste do Estado de Goiás (figura 1), o Parque Nacional das Emas (PNE) foi criado no ano de 1961, tendo seus limites revistos no ano de 1972, apresentando uma área total de 132.813 ha e uma Zona de Amortecimento com 263.432 ha, que não cumpre totalmente o seu papel ecológico por estar intensamente ocupada por atividades agropecuárias, dando à unidade de conservação um aspecto de "ilha" em meio a um mosaico de atividades de agricultura e pecuária. O PNE ocupa parte dos municípios de Chapadão do Céu e Mineiros em Goiás, e Costa Rica no Mato Grosso do Sul (MMA, 2004).

Vitalli, Zakia e Durigan (2009) destacam que a integridade das unidades de conservação e sua efetividade em cumprir suas funções ambientais dependem da criação de "Zonas Tampão", que devem funcionar como filtros, contendo os efeitos de borda causados pela fragmentação dos ecossistemas e "impedindo que atividades antrópicas externas coloquem em risco os ecossistemas naturais dentro das áreas protegidas". "(...) A regulamentação das atividades nessa zona deveria ser, portanto, uma das práticas conservacionistas a ser incorporada pelas unidades de conservação" (VITALLI, ZAKIA e DURIGAN, 2009, p.68).

De acordo com o Sistema Nacional de Unidades de Conservação (SNUC, 2000), a Zona de Amortecimento deve ter seus limites estabelecidos no Plano de Manejo e no caso do Parque Nacional das Emas, apresenta uma área duas vezes maior que à área do parque, abrangendo partes dos territórios dos municípios de Chapadão do 
Céu, Serranópolis e Mineiros, em Goiás, Costa Rica e Alcinópolis no Mato Grosso do Sul e Alto Taquari, no Mato Grosso (MMA, 2004).

Figura 1 - Localização do Parque Nacional das Emas e Zona de Amortecimento.

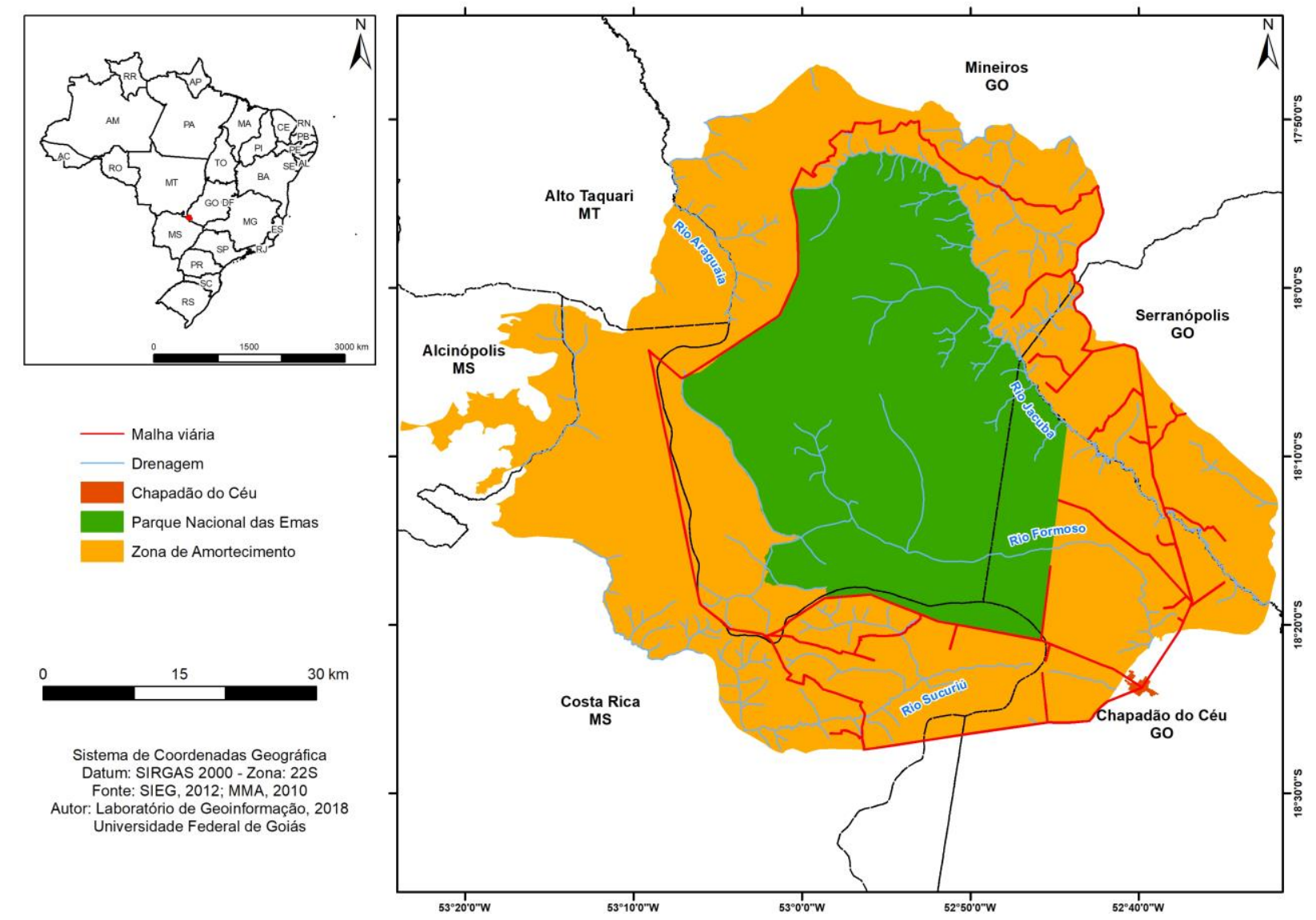

Fonte: Autores (2018)

O Plano de Manejo do Parque Nacional das Emas, elaborado em 2004, define em seu item 4.5.3 os vértices que delimitam a Zona de Amortecimento, e no item 4.6, algumas normas gerais para uso, principalmente, para o uso de agrotóxicos. De acordo com o Plano de Manejo, em uma faixa de $2 \mathrm{~km}$ contígua às áreas do PNE e nas APPs que margeiam os cursos d'água da Zona de Amortecimento, é permitido somente o uso de agrotóxicos pouco ou muito pouco tóxicos (classe IV), considerada como faixa verde. Dispõe ainda de instruções sobre armazenamento, lavagem e destinação das embalagens de agrotóxicos, limitando ainda sua aplicação via aérea em uma faixa de $2 \mathrm{~km}$ da Unidade de Conservação. Outro ponto importante, diz respeito às reservas legais das propriedades, que teriam um prazo de 2 anos para se 
adequar ao Plano de Manejo (até 2006), sendo que as reservas das propriedades confrontantes ao PNE deverão ser localizadas preferencialmente junto aos limites do parque, objetivando a conectividade com outras áreas de preservação (MMA, 2004).

Visto a intensa ocupação agropecuária, este artigo apresenta como objetivo analisar os diferentes elementos que compõem a paisagem na Zona de Amortecimento do Parque Nacional das Emas, indicando as áreas mais vulneráveis e que necessitam de ações urgentes do poder público para a sua conservação.

Entende-se aqui, que a combinação de elementos físicos, biológicos e antrópicos atribuem à paisagem uma característica de conjunto, indissociável e em evolução permanente (BERTRAND, 1972).

\section{MATERIAL E MÉTODOS}

Para o desenvolvimento da pesquisa, foram consideradas duas etapas, sendo uma em campo com a realização de levantamentos e observações, e outra em laboratório, com a realização de mapeamentos e a análise da área em conjunto com as informações coletadas em campo.

Inicialmente, foram realizados levantamentos bibliográficos e documentais, a fim de criar um completo banco de dados geográficos sobre a área de interesse, especialmente para a Zona de Amortecimento do Parque Nacional das Emas. Entre os documentos, foi realizada a leitura do Plano de Manejo do parque, do Plano Nacional do Meio Ambiente, do Código Florestal Brasileiro e do Sistema Nacional de Unidades de Conservação. Também foi realizada uma pesquisa sobre artigos científicos sobre a temática abordada, buscando encontrar metodologias adequadas para o estudo.

Para a criação do banco de dados geográficos, foram levantadas informações em formato "shapefile" (.shp) dos temas: Geologia, Relevo, Solos, Recursos Hídricos, Malha Viária e Clima, além de informações socioeconômicas sobre ocupação do território e principais atividades produtivas nos municípios que compõem a Zona de Amortecimento do Parque Nacional das Emas. Também compõem o banco de dados imagens do satélite Sentinel2, com resolução espacial de 10 metros e do sensor 
PALSAR/ALOS, com imageamento do relevo em resolução de $12,5 \mathrm{~m}$, permitindo o mapeamento da região em escala detalhada.

A análise do meio físico seguiu as recomendações da Avaliação Ambiental Integrada proposta por Tucci e Mendes (2006) e da análise de Fragilidade Ambiental proposto por Ross (1994). Foram elaborados os seguintes produtos cartográficos: a) Mapa de Geologia, com base nos dados disponibilizados pela CPRM; b) Mapa de Solos, a partir de informações espaciais disponibilizadas pela EMBRAPA; c) Relevo (declividade e hipsometria) a partir de imagens do sensor PALSAR/ALOS disponibilizadas pelo Serviço Geológico dos Estados Unidos (USGS); d) Recursos Hídricos, elaborados a partir das mesmas imagens do sensor ALOS/PALSAR. Os estudos climáticos foram desenvolvidos a partir de informações disponibilizadas pelo Instituto Nacional de Meteorologia (INMET) para a estação convencional de Jataí e para a estação automática de Chapadão do Sul (MS), visto que não existem estações meteorológicas próximas à área de estudo. As informações socioeconômicas foram obtidas nos domínios eletrônicos do Instituto Brasileiro de Geografia e Estatística (IBGE).

Foram utilizadas, ainda, imagens do aplicativo Google Earth PRO, bases cartográficas disponibilizadas pelo Sistema Estadual de Geoinformação de Goiás (SIEG) e pelo IBGE. Todos os mapeamentos foram desenvolvidos utilizando o software ArcGIS $10.1{ }^{\circledR}$, licenciado para o Laboratório de Geoinformação da UFG/Regional Jataí, bem como a estrutura física e equipamentos do laboratório.

Para o mapeamento de uso e cobertura da terra foram utilizadas imagens do satélite SENTINEL2, do dia 18 de outubro de 2017 com resolução espacial de $10 \mathrm{~m}$, onde foi realizada a composição das bandas: 3 (Azul - $490 \mathrm{~nm}), 4$ (Verde - $560 \mathrm{~nm}), 5$ (Vermelho - $665 \mathrm{~nm}$ ) e 8 (Infravermelho Próximo - $842 \mathrm{~nm}$ ), obtidas de forma gratuita no domínio eletrônico do serviço geológico dos Estados Unidos - USGS (United States Geological Survey).

Foi realizado um processo de classificação não supervisionada por segmentação, considerando 150 classes, com área máxima de 5 pixels e variação de 5 tonalidades de cinza, posteriormente reclassificadas considerando as classes: 
Agricultura, Pecuária, Silvicultura, Água, Áreas Úmidas, Fitofisionomias de Cerrado, Formações Florestais (Matas Ciliar, de Galeria e Cerradão) e áreas com solo descoberto, posteriormente reclassificadas em agricultura e pecuária.

Os trabalhos de campo foram realizados entre os dias 10 e 13 de maio de 2018, quando toda a área de estudo foi percorrida, georreferenciada e registrada por meio de levantamento fotográfico (Figura 2). Ao todo foram percorridos cerca de $1000 \mathrm{~km}$ nos municípios de Chapadão do Céu, Serranópolis, Costa Rica e Mineiros.

Os levantamentos de campo seguiram as recomendações do Manual para Levantamento Utilitário do Meio Físico e Classificação de Terras no Sistema de Capacidade de Uso (LEPSCH, 1991) e dos manuais técnicos do IBGE de Geomorfologia (2009), Pedologia (2015) e Uso da Terra (2013). Foi realizado o registro fotográfico de todos os pontos e coletadas amostras de solo para análise empírica a fim de confirmar as informações contidas nos mapeamentos disponibilizados pela EMBRAPA. 
Figura 2 - Rotas de campo e pontos de amostragem.

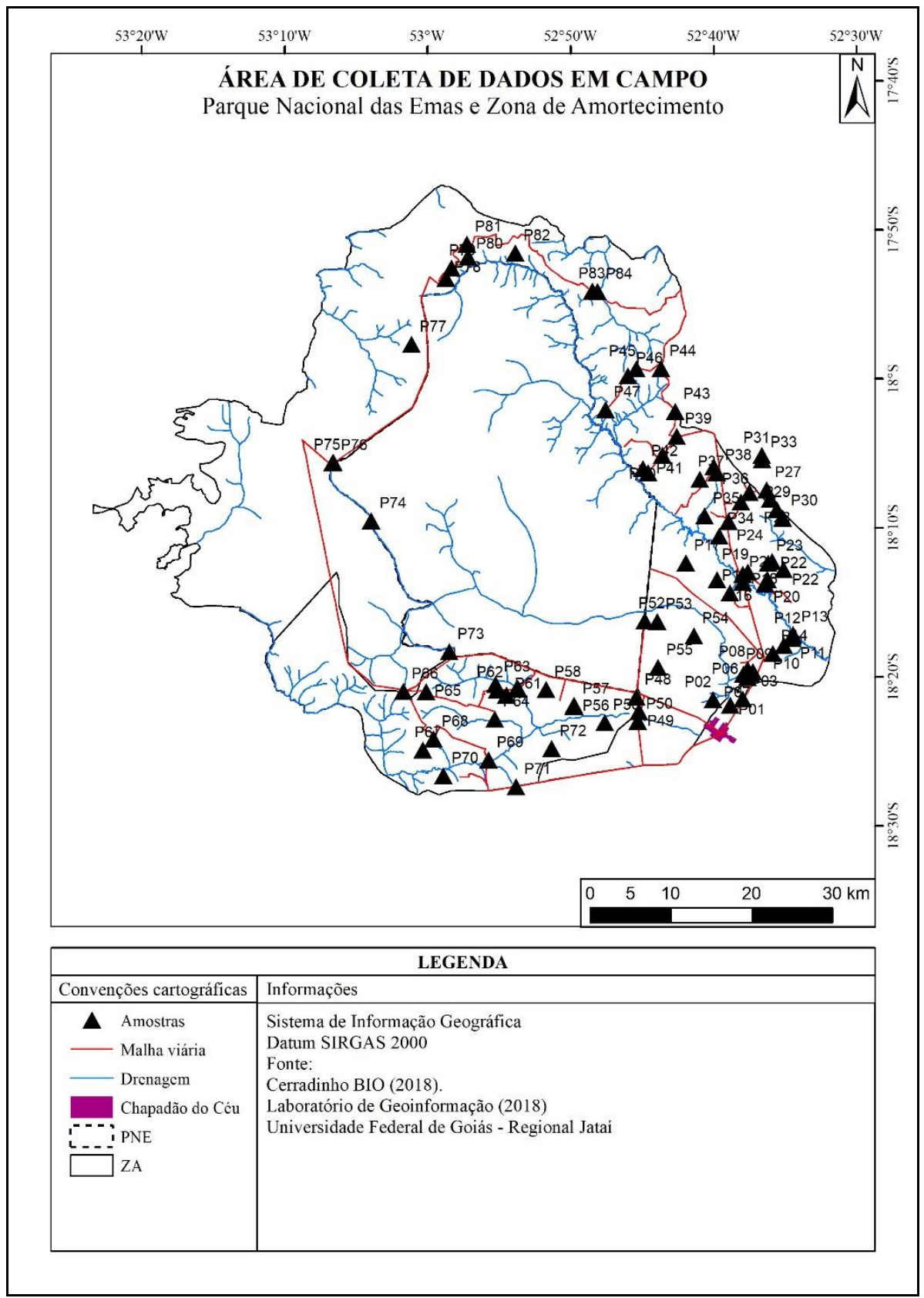

Fonte: Autores (2018)

O mapeamento de Fragilidade Ambiental foi desenvolvido de acordo com a metodologia proposta por ROSS (1994) e adaptada por autores como Kawakubo et al (2005) e Alves (2012), destacando que os estudos analíticos de fragilidade são de grande importância ao planejamento ambiental, onde conservação e recuperação ambiental estão lado a lado com o desenvolvimento tecnológico, econômico e social. 
O conhecimento das potencialidades dos recursos naturais passa pelos levantamentos dos solos, relevo, rochas e minerais, das águas, do clima, da flora e fauna, enfim de todas as componentes do estrato geográfico que dão suporte a vida animal e do homem. Para análise da fragilidade, entretanto, exige-se que esses conhecimentos setorizados sejam avaliados de forma integrada, calcada sempre ao princípio de que a natureza apresenta funcionalidade intrínseca entre as suas componentes físicas e bióticas (ROSS, 1994).

Dessa forma, foram realizados mapeamentos de solo e relevo que, em conjunto com dados de potencial erosivo das chuvas (erosividade), compõem o mapa de Fragilidade Potencial do Ambiente, que é a fragilidade apresentada pelo meio independente da ação antrópica. Este produto, ao ser cruzado com o mapa de grau de proteção do ambiente pelo uso da terra, origina o mapa de Fragilidade Emergente, ou Fragilidade Ambiental, classificando as áreas em níveis de fragilidade que vão de muito baixa a muito alta, servindo como parâmetro para definição de atividades mais adequadas ao ambiente, sem colocar em risco sua estabilidade e evitando a perda de solos por erosão (ROSS, 1994).

O mapeamento da Capacidade de Uso dos Recursos Naturais seguiu os parâmetros definidos por Lepsch (1991), que propõe o estabelecimento de três grandes classes de capacidade de uso: A - Terras passíveis de utilização com culturas anuais, perenes, pastagens, reflorestamento e conservação da vida silvestre; B - Terras impróprias para cultivos intensivos, mas ainda adaptadas para pastagens, reflorestamento e conservação da vida silvestre; C - Terras não adequadas para cultivos anuais, perenes, pastagens ou reflorestamento, podendo servir apenas como abrigo e proteção da fauna e flora silvestre, recreação ou armazenamento de água. A metodologia propõe subclasses, baseadas no nível de manejo e práticas conservacionistas necessários para a utilização, além de delimitar fatores de limitação relacionados ao relevo (como o risco de erosão, por exemplo), ao solo (pedregosidade, profundidade, etc), ao excesso de água e a questões climáticas (déficit ou excedente hídrico e etc).

Com base na metodologia descrita por Lepsch (1991), nas legislações ambientais vigentes e nas características ambientais da área de estudo, foram definidas nesta pesquisa como áreas impróprias para uso agropecuário: a) Faixa de 
100 metros a partir das margens dos cursos d'água; b) Áreas úmidas, com presença de solos hidromórficos (gleissolos); c) Áreas com declividades superiores a 30\%; d) Área do Parque Nacional das Emas. Para as demais áreas foram analisados fatores limitantes com relação aos solos e ao relevo, visto que as características climáticas da região são favoráveis ao desenvolvimento de atividades agropecuárias.

Foi realizado um estudo de possibilidade de alocação de Unidades de Conservação e criação de Corredores Ecológicos para a conservação da biodiversidade, considerando o aspecto de "ilha" apresentado pelo Parque Nacional das Emas. O objetivo é procurar formas de conectar a Unidade de Conservação a outras bacias hidrográficas e áreas que apresentem vegetação natural ainda conservadas.

O mapeamento foi baseado nos estudos de Cabral e Souza (2005), Matsumoto et. al. (2012) e Santos (2018) e considerou as seguintes variáveis: a) Faixa de 100 metros a partir de cada margem dos cursos d'água; b) Áreas úmidas; c) Áreas com declividade superior a 25\%; d) Remanescentes de vegetação natural, com área superior a 100 ha. Após o cruzamento das informações, foram identificadas áreas com baixo, médio e alto potencial para alocação de unidades de conservação, além da indicação de áreas propícias para a criação de corredores ecológicos.

Embora não tenham sido identificadas áreas significativas com potencial alto ou médio para alocação de Unidades de Conservação, sugere-se que a criação dessas áreas sejam feitas como forma de compensação ambiental pelo uso agrícola da Zona de Amortecimento do Parque Nacional das Emas.

Apesar de o parque ser cercado por estradas, ferrovias e áreas de intenso uso agrícola, é possível estabelecer conexões entre a Unidade de Conservação e as bacias dos rios Corrente, Verde, Sucuriú e Araguaia, seja por meio de corredores, seja pela criação de Áreas de Proteção Ambiental ou Reservas Particulares do Patrimônio Natural. 


\section{RESULTADOS E DISCUSSÃO}

O Parque Nacional das Emas, assim como sua Zona de Amortecimento, localizase predominantemente sobre áreas de topografia plana a suave ondulada (Figura 3), com predominância de áreas de chapada com altitudes superiores a 800 m, embora sejam encontradas áreas com altitudes entre 600 e 750 m nos fundos de vale.

Figura 3 - Visão panorâmica de área de plantio de cana-de-açúcar em relevo plano na bacia do Rio Formoso - Chapadão do Céu (GO).

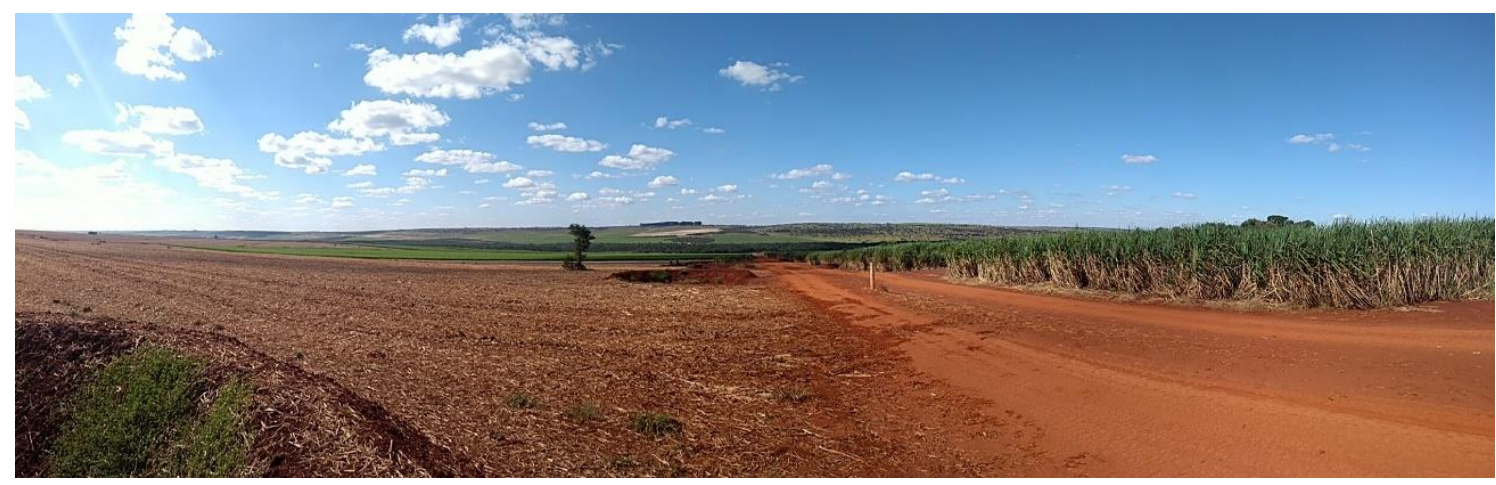

Fonte: Acervo particular dos autores (maio de 2018)

Cerca de $86 \%$ da área é representada por relevos planos (Figura 4), com inclinações de até $6 \%$, característica de áreas de topo do Brasil Central conhecidas como "Chapadões". 98\% da área apresenta inclinações inferiores a 12\%, se mostrando como ideais para a agricultura mecanizada e sendo um dos principais fatores que fizeram da região um dos principais pontos de investimento na agricultura comercial por parte de planos do Governo Federal nas décadas de 1970 e 1980 (em conjunto com os municípios de Jataí, Rio Verde e Montividiu). Apenas 1,2\% da área encontra-se em locais com inclinações superiores a $30 \%$ e, portanto, inaptas para a ocupação agropecuária.

A topografia da área justifica-se por sua litoestratigrafia, representada principalmente pela formação Cachoeirinha $(56,1 \%)$, constituída por argilas, areias brancas, amarelas e avermelhadas, intercalados com conglomerados lateríticos e pelas coberturas detríticas indiferenciadas (3\%), que constituem áreas recobertas por areias finas a grossas, formando terraços argilo-arenosos com cascalhos dispersos e níveis 
de material ferruginoso transportado (GUERRA et al, 1989). Ambas as formações são relativamente recentes, considerando a história geológica da Terra, com origem nos períodos Terciário e Quaternário da Era Cenozóica, recobrindo extensas áreas de Chapadões no Sudoeste de Goiás (Figura 5).

Figura 4 - Declividade.

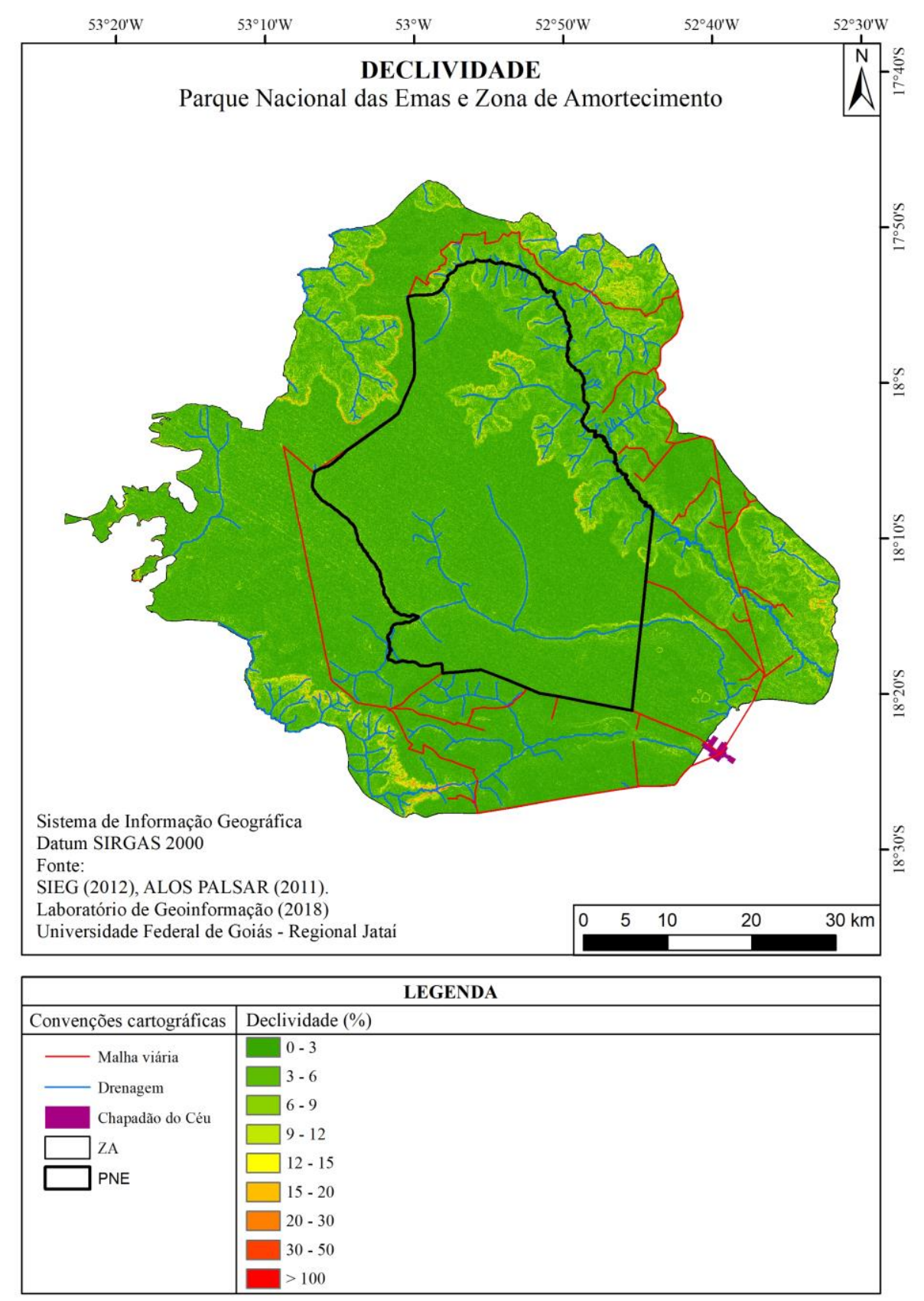

Fonte: Autores (2018)

Figura 5 - Formações geológicas. 


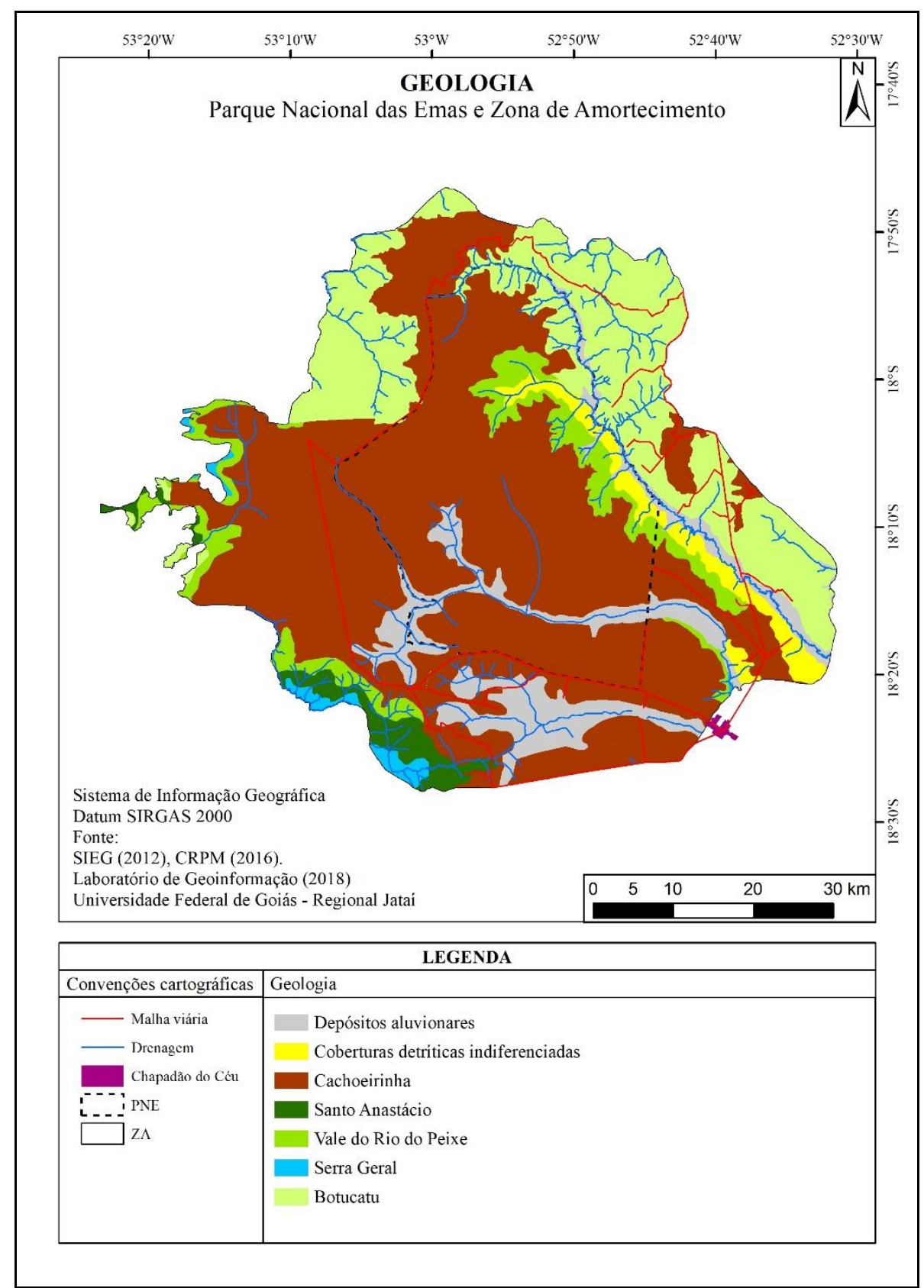

Fonte: Autores (2018)

$\mathrm{Na}$ figura 5, é possível observar que, além das formações sedimentares terciárias e quaternárias, destaca-se a Formação Botucatu, também sedimentar, mas que data da era Mesozoica. Representando 21,8\% da área total, principalmente em superfícies erosivas associadas aos vales dos Rios Jacuba e Araguaia, a Formação Botucatu encontra-se associada a áreas com declividade mais acentuada e altitudes entre 600 e 750 m. É constituída por arenitos eólicos friáveis de granulação média a fina e de cor rosa, sendo observada em diversos afloramentos no município de Serranópolis. Devido às características de seus arenitos, os solos associados à 
Formação Botucatu são muito arenosos, chegando a apresentar áreas com teor de areia superior a 90\%, o que confere uma maior fragilidade a estes ambientes devido ao risco acentuado de erosão.

Outra formação bastante significativa, recobrindo $9,8 \%$ da região são os Depósitos Aluvionares, de formação relativamente recente assim como a Formação Cachoeirinha e as Coberturas Detríticas. Em sua maioria, encontram-se associados ao alto curso de rios como o Sucuriú e o Formoso, em áreas de topografia plana (Figura 6). Esses depósitos são constituídos em sua maioria por cascalho grosseiro, mal selecionado, matriz arenosa e seixos arredondados de quartzo (BRASIL, 1983; GUERRA et al, 1989).

Figura 6 - Área úmida localizada nas nascentes do rio Sucuriú, desenvolvida sobre áreas de depósitos aluvionares e com ocorrência de gleissolos - Costa Rica/MS.

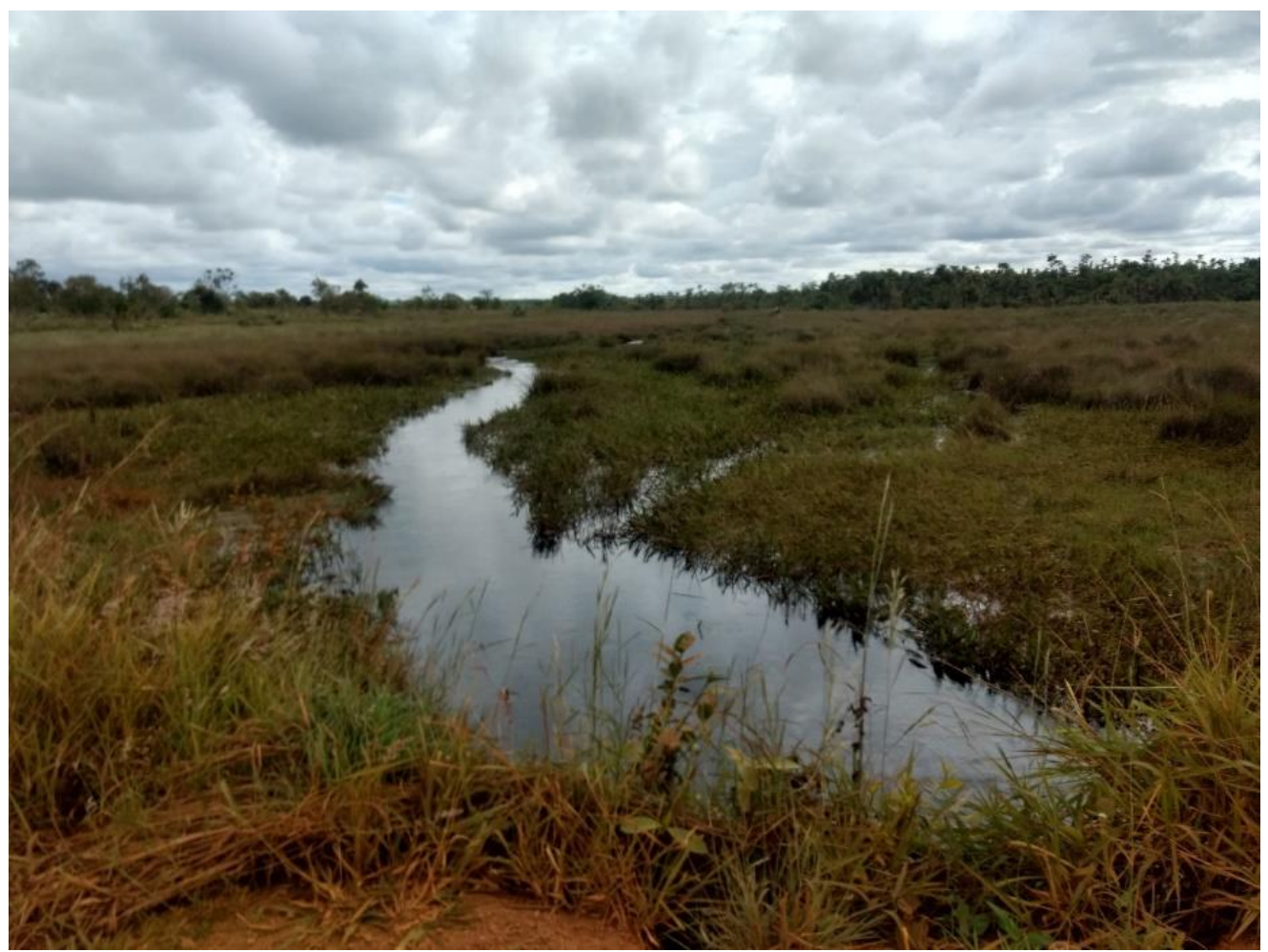

Fonte: Acervo particular dos autores (maio de 2018)

Estas áreas associam-se a fundos de vale planos em altitudes superiores a 750 m e apresentam como característica marcante o hidromorfismo do solo, estando 
associadas a áreas de gleissolos, onde se verificam diferentes pontos de afloramento de água, indicando a proximidade dos lençóis subterrâneos com a superfície. Estes solos apresentam uma grande importância ambiental, especialmente para a manutenção do fluxo hídrico das bacias hidrográficas da região, que dão origem a uma paisagem singular, com espécies que ocorrem apenas neste tipo de ambiente. $\mathrm{O}$ uso destas áreas em atividades agropecuárias, especialmente com a construção de drenos para diminuir a quantidade de água no perfil do solo, podem afetar de forma irreversível os cursos d’água da região.

Com menor expressão espacial, destacam-se as formações Vale do Rio do Peixe e Santo Anastácio (Sedimentares), com 6,1\% e 2,3\% de área, respectivamente, e a Formação Serra Geral (Ígnea), composta por basaltos provenientes de derrames vulcânicos da Era Mesozóica, ocupando menos de 1\% da área total. A Formação Vale do Rio do Peixe aparece associada à Formação Botucatu, apresentando litologia composta por arenitos de coloração creme e vermelhos, mal classificados com grãos arredondados (GUERRA et al, 1989) e originando solos com alto teor de areias em sua composição e, consequentemente, bastante susceptíveis à erosão.

Com relação aos solos (Figura 7), predominam diferentes variações dos latossolos, que ocupam $70,7 \%$ da área total, associados a regiões de topografia plana e altitudes superiores a $800 \mathrm{~m}$. Apesar de apresentarem acidez e baixa fertilidade em alguns pontos, estes solos são facilmente corrigidos e amplamente utilizados para práticas agrícolas, tendo como principais vantagens a profundidade, a estabilidade (baixa susceptibilidade à erosão), a boa drenagem e a possibilidade de mecanização pela associação com relevos planos. Na classe dos latossolos observa-se a presença das subordens Latossolo Vermelho Escuro (álico e distrófico) e Vermelho Férrico como predominantes, conforme a base cartográfica do Mapeamento dos Solos do Brasil disponibilizada pela EMBRAPA. 
Figura 7 - Solos.

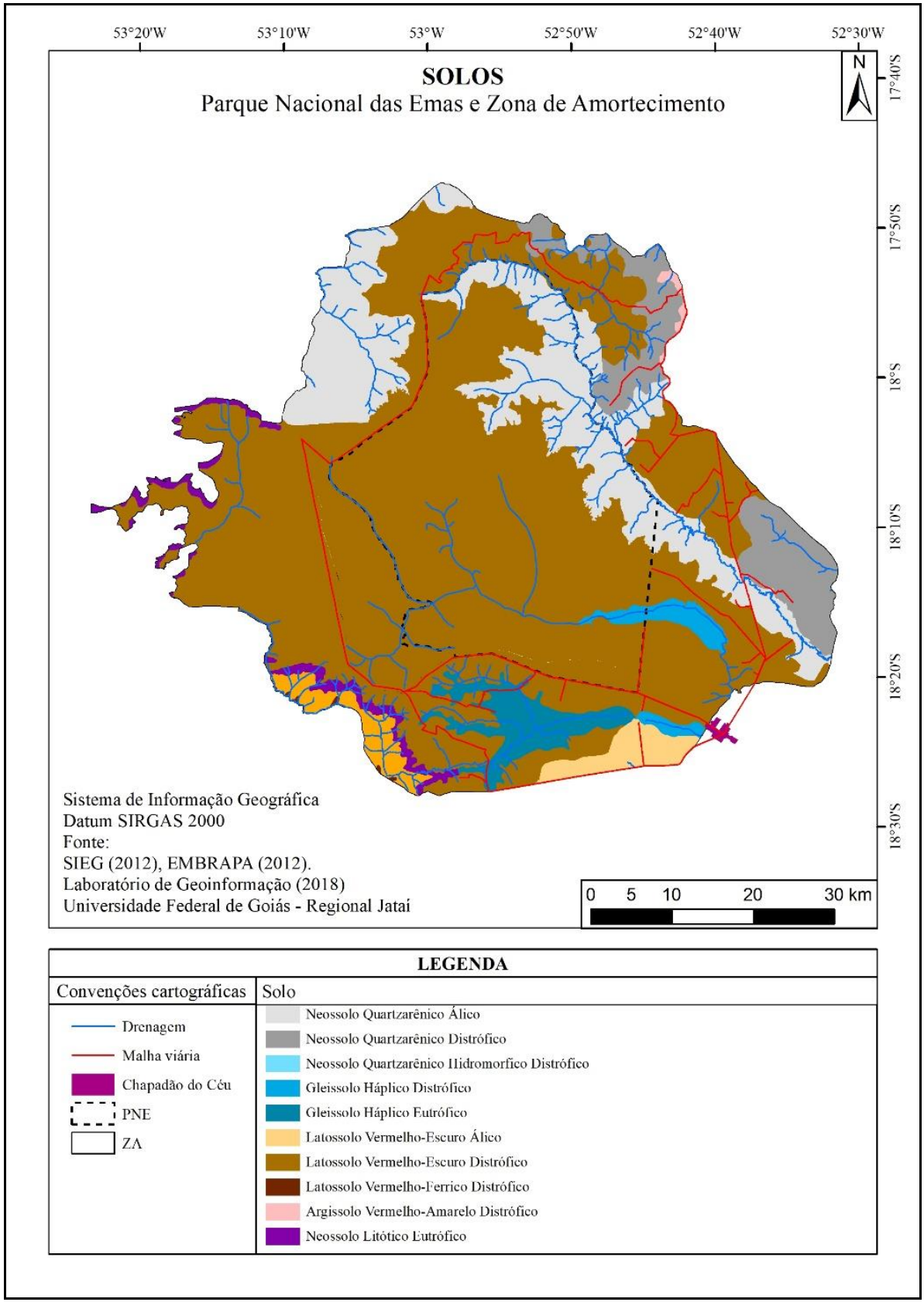

Fonte: Autores (2018)

A segunda categoria mais significativa são os Neossolos Quartarênicos, que recobrem $23,2 \%$ da área total, especialmente nos vales dos Rio Jacuba e Araguaia, associados a áreas embasadas pelos arenitos das Formações Botucatu e Vale do Rio do Peixe e com declividades mais acentuadas, em cotas inferiores a $750 \mathrm{~m}$. Estes solos apresentam alto teor de areia e recobrem boa parte dos municípios de Serranópolis e Mineiros, associados sempre a formações areníticas e relevo suave ondulado a 
ondulado. Demonstram os maiores níveis de fragilidade entre os solos identificados na área devido à pouca agregação de seus componentes, o que os tornam altamente susceptíveis à erosão. Embora apareçam em diferentes áreas ocupados pelo cultivo de cana-de-açúcar, exigem a adoção de uma série de técnicas conservacionistas para evitar a erosão, como o plantio em curva de nível e a construção de caixas de contenção ao longo das estradas. São mais aptos ao cultivo de pastagens, florestas plantadas (silvicultura) e à conservação do ambiente.

Os gleissolos representam 4,4\% da área de estudo, encontrando-se associados aos depósitos aluvionares, onde ocorre o afloramento do lençol subsuperficial, áreas de nascentes e a constituição de paisagens como as áreas úmidas, conhecidas regionalmente como várzeas ou "varjões". São áreas extremamente frágeis do ponto de vista ambiental por apresentarem solos arenosos com presença de hidromorfismo, fator limitante para a ocupação com atividades agrosilvopastoris. Quando drenadas, como acontece em diferentes pontos do alto curso do Rio Sucuriú, se mostram aptas para o cultivo agrícola e para o desenvolvimento da pecuária, embora seu uso recomendado seja para conservação do ambiente, visto sua importância como reguladora do fluxo hídrico superficial (Figura 8).

De acordo com o Código Florestal Brasileiro (lei No 12.651, de 25 de maio de 2012) e a lei $N^{0}$ 12.727, de 17 de outubro de 2012 (que altera a Lei no 12.651, de 25 de maio de 2012, que dispõe sobre a proteção da vegetação nativa; altera as Leis nos 6.938, de 31 de agosto de 1981, 9.393, de 19 de dezembro de 1996, e 11.428, de 22 de dezembro de 2006; e revoga as Leis nos 4.771, de 15 de setembro de 1965, e 7.754, de 14 de abril de 1989, a Medida Provisória no 2.166-67, de 24 de agosto de 2001, o item 22 do inciso II do art. 167 da Lei no 6.015, de 31 de dezembro de 1973, e o § 20 do art. 4o da Lei no 12.651, de 25 de maio de 2012), as áreas úmidas (Artigo $3^{\circ}$, inciso XXV) são pantanais e superfícies terrestres cobertas de forma periódica por águas, cobertas originalmente por florestas ou outras formas de vegetação adaptadas à inundação. O Código Florestal Goiano (lei No 18.104, de 18 de julho de 2013) também traz o mesmo conceito para estas áreas, que devem ser conservadas em uma faixa igual às das faixas marginais de qualquer curso d'água ou reservatório, não 
sendo consideradas as várzeas situadas fora destes limites como área de preservação permanente. No caso de veredas, prevê-se uma faixa de preservação de 50 metros a partir do espaço permanentemente brejoso e encharcado.

Figura 8 - Plantio de cana-de-açúcar sobre gleissolos, no município de Costa Rica/MS.

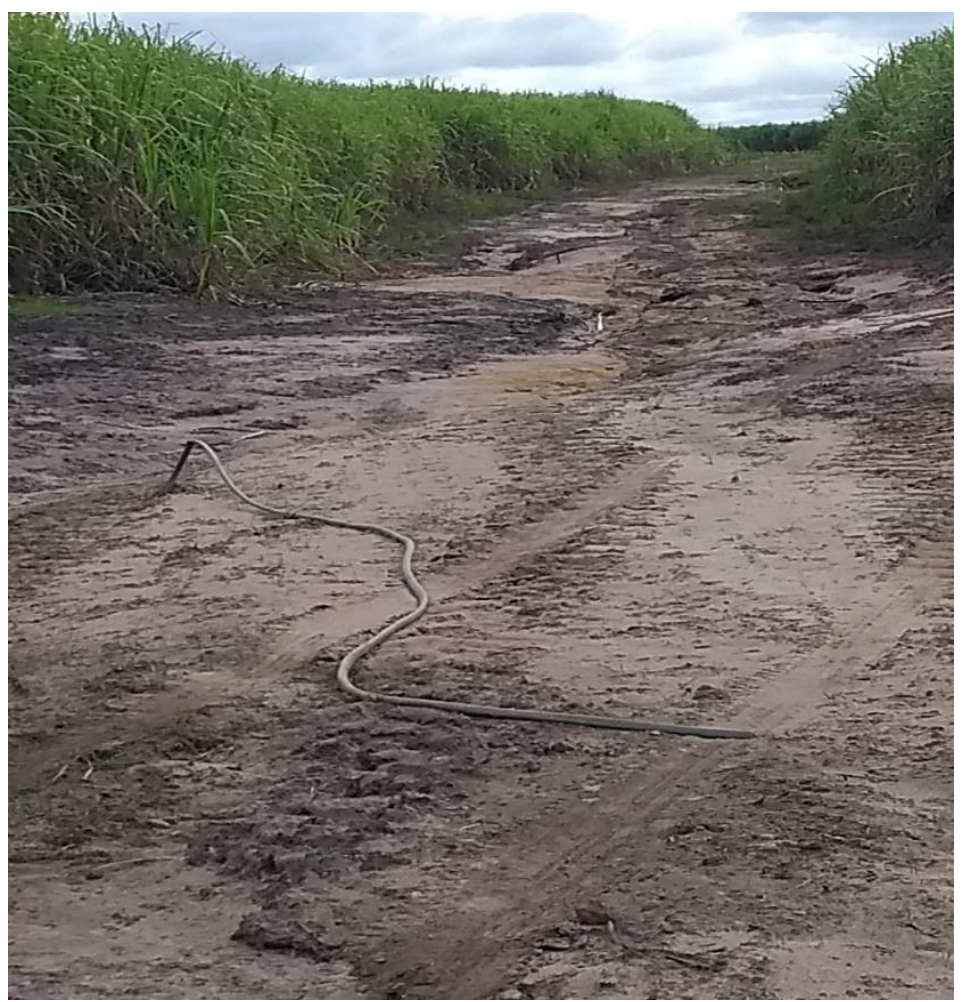

Fonte: Acervo particular dos autores (maio de 2018)

As áreas úmidas, mapeadas por imagens de satélite, representam 2,1\% da área total de estudo e, se consideradas as áreas mapeadas como gleissolos, tendo um percentual de 4,4\% da área. Embora ocupadas por diversas práticas agropecuárias, especialmente no município de Costa Rica, a conservação destas áreas é fundamental para preservar a "produção de água" na bacia.

Em menor representatividade percentual de área, encontram-se os Neossolos litólicos $(1,5 \%)$, observados em áreas com declividade mais acentuada nas encostas do chapadão e os Argissolos (0,2\%), especialmente os Argissolos vermelho-amarelos, associados às áreas de Latossolos.

O Clima da área de estudo caracteriza-se como do tipo Aw segundo a classificação de Köppen (AYOADE, 2010), apresentando duas estações bem definidas, 
sendo uma chuvosa, de outubro a março/abril e uma estação seca, de abril a setembro. A pluviosidade média na região é de aproximadamente $1200 \mathrm{~mm}$, com precipitações concentradas de outubro a março, conforme pode ser observado no climograma da cidade de Chapadão do Sul/MS (figura 9).

\section{Figura 9 - Climograma do município de Chapadão do Sul (MS).}

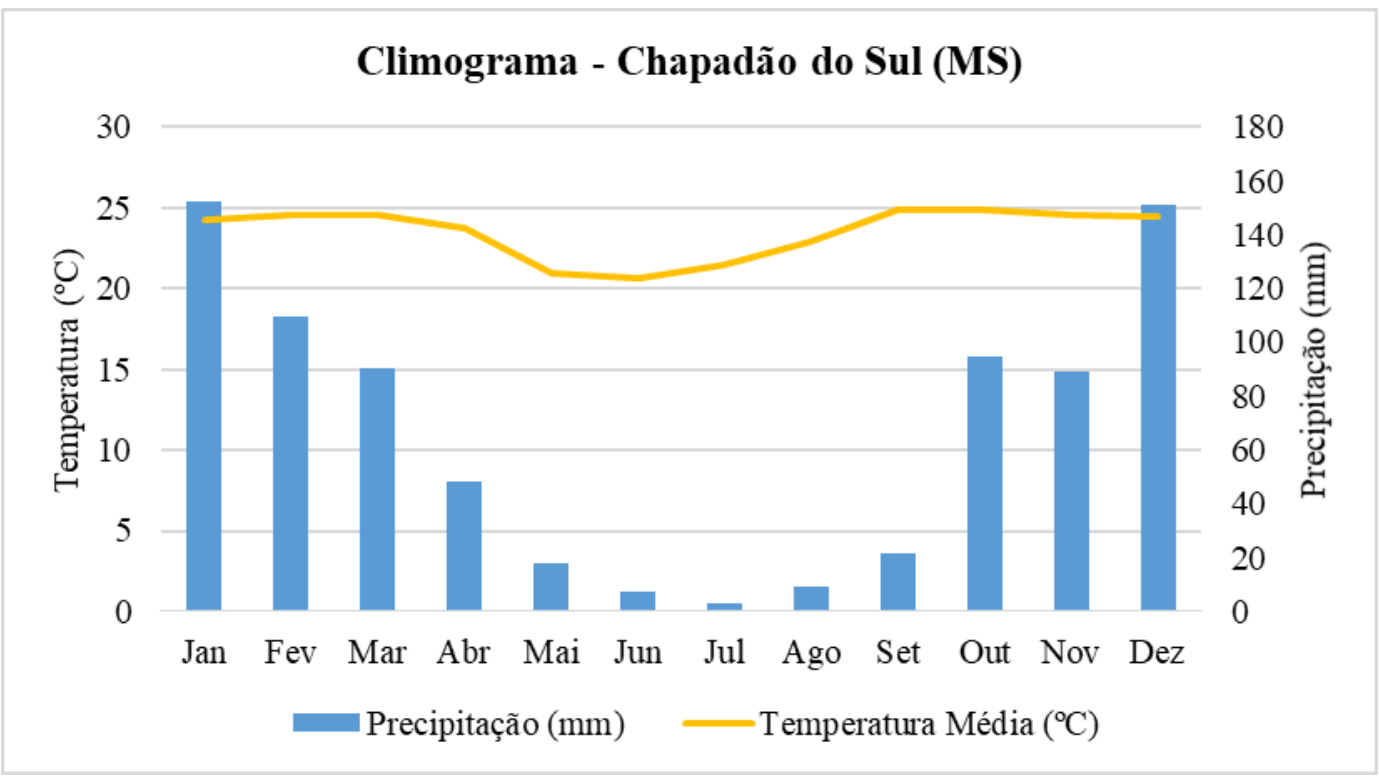

Fonte: Autores (2018)

A temperatura média anual é de $24^{\circ} \mathrm{C}$, com pequenas variações na amplitude térmica média ao longo do ano. As menores temperaturas são registradas entre meses de maio e julho e as maiores temperaturas são registradas nos meses de setembro e outubro, quando também são registrados índices muito baixos de umidade relativa do ar. A ausência de estações climatológicas com séries históricas disponíveis é um problema para a realização de estudos ambientais, visto que a mais próxima localiza-se no município de Chapadão do Sul, no Mato Grosso do Sul.

O Parque Nacional das Emas e sua Zona de Amortecimento encontram-se em uma região caracterizada pelos altos índices de produtividade no campo. O município de Chapadão do Céu, por exemplo, figura entre os maiores produtores de grãos do Estado de Goiás, principalmente de milho e soja, com uma média anual de 93.000 ha colhidos de soja nos últimos 10 anos. A partir do ano de 2009, torna-se significativo 
também o cultivo de cana-de-açúcar, que chega a uma área colhida de 45.000ha em 2013, apresentando atualmente uma área média de 27.000 ha colhidos no município.

Na Zona de Amortecimento do Parque Nacional das Emas que, além do município de Chapadão do Céu, abrange áreas dos municípios de Serranópolis e Mineiros, em Goiás, Costa Rica e Alcinópolis, no Mato Grosso do Sul, e Alto Taquari em Mato Grosso, 63,7\% da área é ocupada por atividades agrícolas, sobretudo grãos (Figura 10).

De um total de $2.634,3 \mathrm{Km}^{2}, 20,1 \%$ da área da Zona de Amortecimento do PNE ainda se encontra recoberta por diferentes fitofisionomias de Cerrado, 2,9\% por formações florestais, matas ciliares e de galeria e cerradão e $2 \%$ por áreas úmidas, totalizando $25 \%$ de áreas ainda conservadas.

Os outros usos identificados na área foram de pastagens, correspondendo a 11,2\% da Zona de Amortecimento, principalmente em áreas dos municípios de Serranópolis e Mineiros caracterizadas por solos mais arenosos e declividades mais acentuadas e de silvicultura em um percentual de área ainda pouco significativo $(0,1 \%)$. Diferentes categorias de corpos d'água recobrem menos de $0,1 \%$ da Zona de Amortecimento (Figura 11).

De acordo com Spörl e Ross (2004), a identificação das fragilidades potenciais e emergentes dos ambientes naturais permitem uma melhor definição de diretrizes e ações a serem implementadas, subsidiando a gestão do território. Para avaliar os diferentes níveis de fragilidade apresentados pelo ambiente, são consideradas quatro variáveis: solos, relevo, potencial erosivo das chuvas (erosividade) e categorias de uso e cobertura da terra. As três primeiras variáveis, definem os níveis de fragilidade potencial do ambiente (Figura 12). 
Figura 10 - Uso e cobertura da terra (2018).

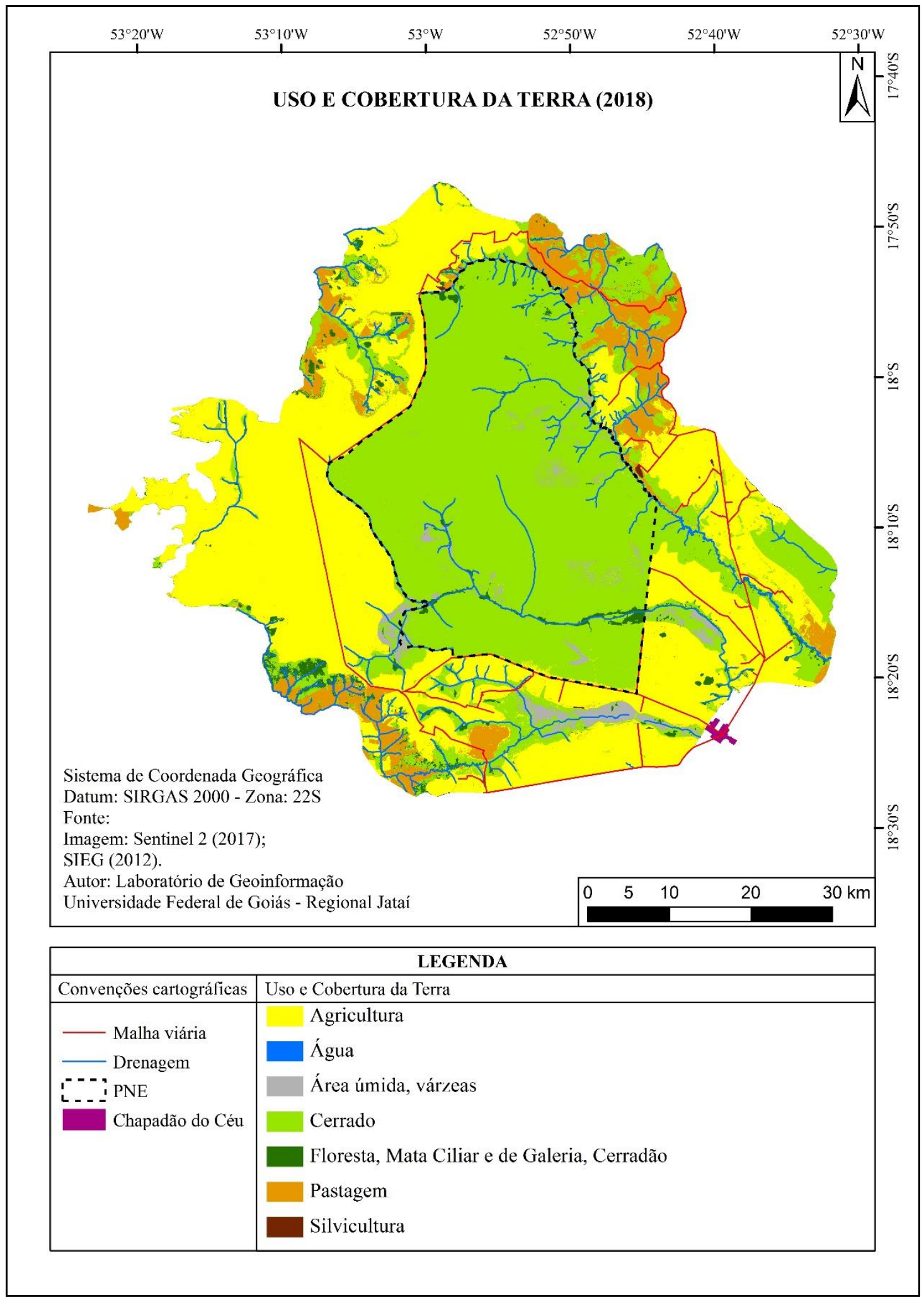

Fonte: Autores (2018) 
Figura 11 - Diferentes categorias de uso e cobertura da terra identificadas na Zona de Amortecimento do Parque Nacional das Emas.
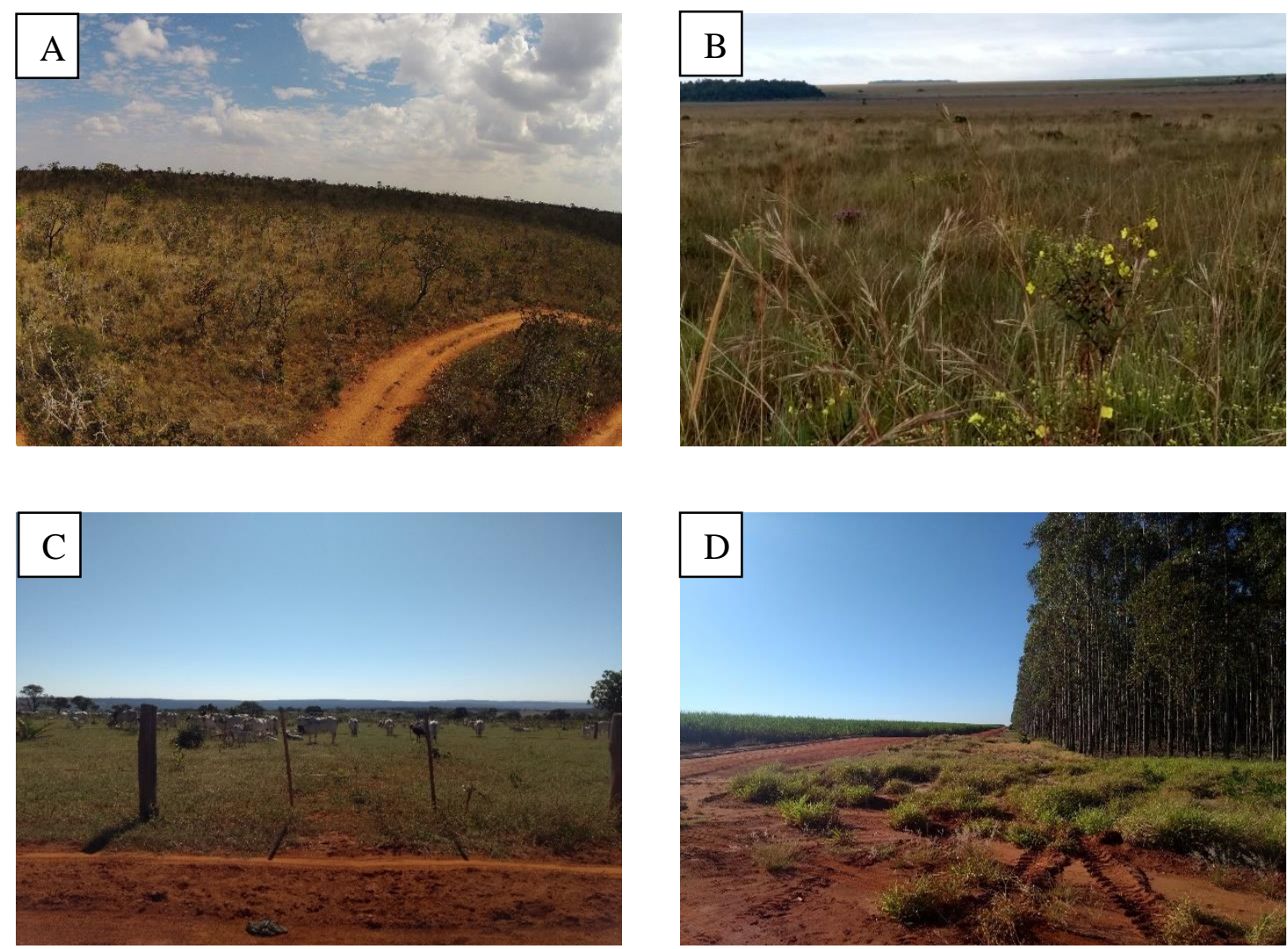

\section{$\mathrm{E}$}

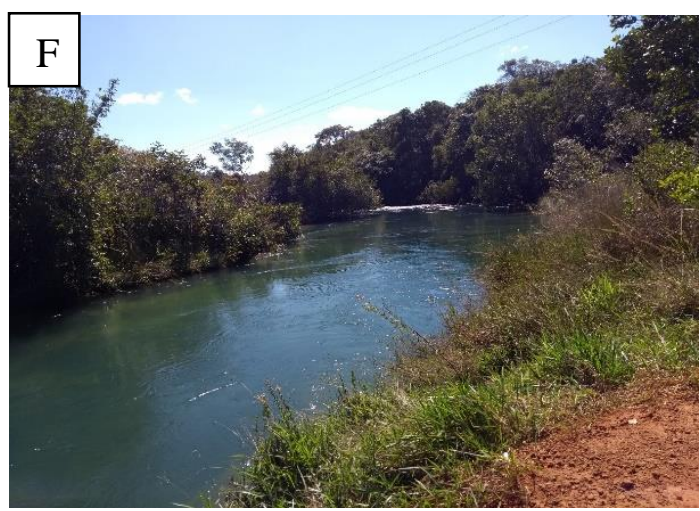

Fonte: Acervo particular dos autores (maio de 2018)

Legenda: A) Campo Limpo no interior do PNE; B) Área úmida no município de Chapadão do Céu (GO); C) Criação de gado de corte no município de Serranópolis (GO); D) Plantio de eucalipto em áreas de latossolo vermelho no município de Chapadão do Céu (GO); E) Em primeiro plano, área de cerrado recém derrubada para plantio no município de Costa Rica (MS). Em segundo plano, área com formações florestais em encosta associadas a áreas com diferentes feições de cerrados; F) Rio Jacuba no limite entre os municípios de Chapadão do Céu e Serranópolis (GO), com destaque para a mata ciliar. 
Figura 12 - Fragilidade potencial (2018).

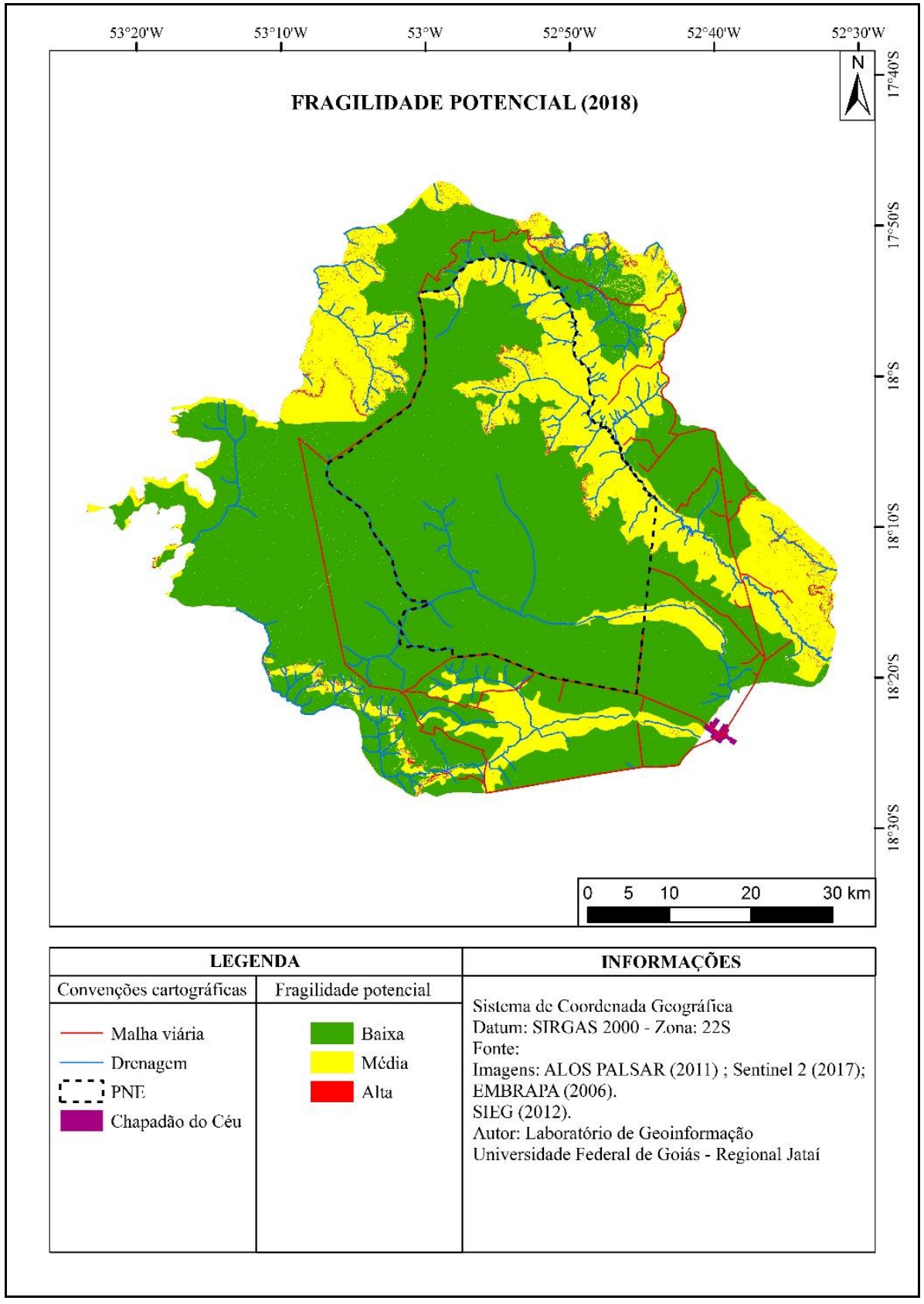

Fonte: Autores (2018)

Ao indicar os diferentes graus de proteção que o uso da terra confere ao ambiente e, em conjunto com o mapeamento da fragilidade potencial, temos a fragilidade emergente do ambiente (Figura 13), entendida aqui como a fragilidade 
ambiental, visto que considera os diferentes níveis de ocupação antrópica sobre o território.

A fragilidade potencial é identificada independentemente das formas de ocupação, demonstrando características naturais do território. Na área de estudo, compreendida aqui como o Parque Nacional das Emas e sua Zona de Amortecimento, $71,6 \%$ do território apresenta fragilidade potencial classificada como baixa (indicada pela cor verde na figura 12), graças à topografia plana, à ocorrência de latossolos e a uma erosividade classificada como média, considerando a distribuição pluviométrica de $1200 \mathrm{~mm}$ no decorrer do ano. 
Figura 13 - Fragilidade emergente (2018).

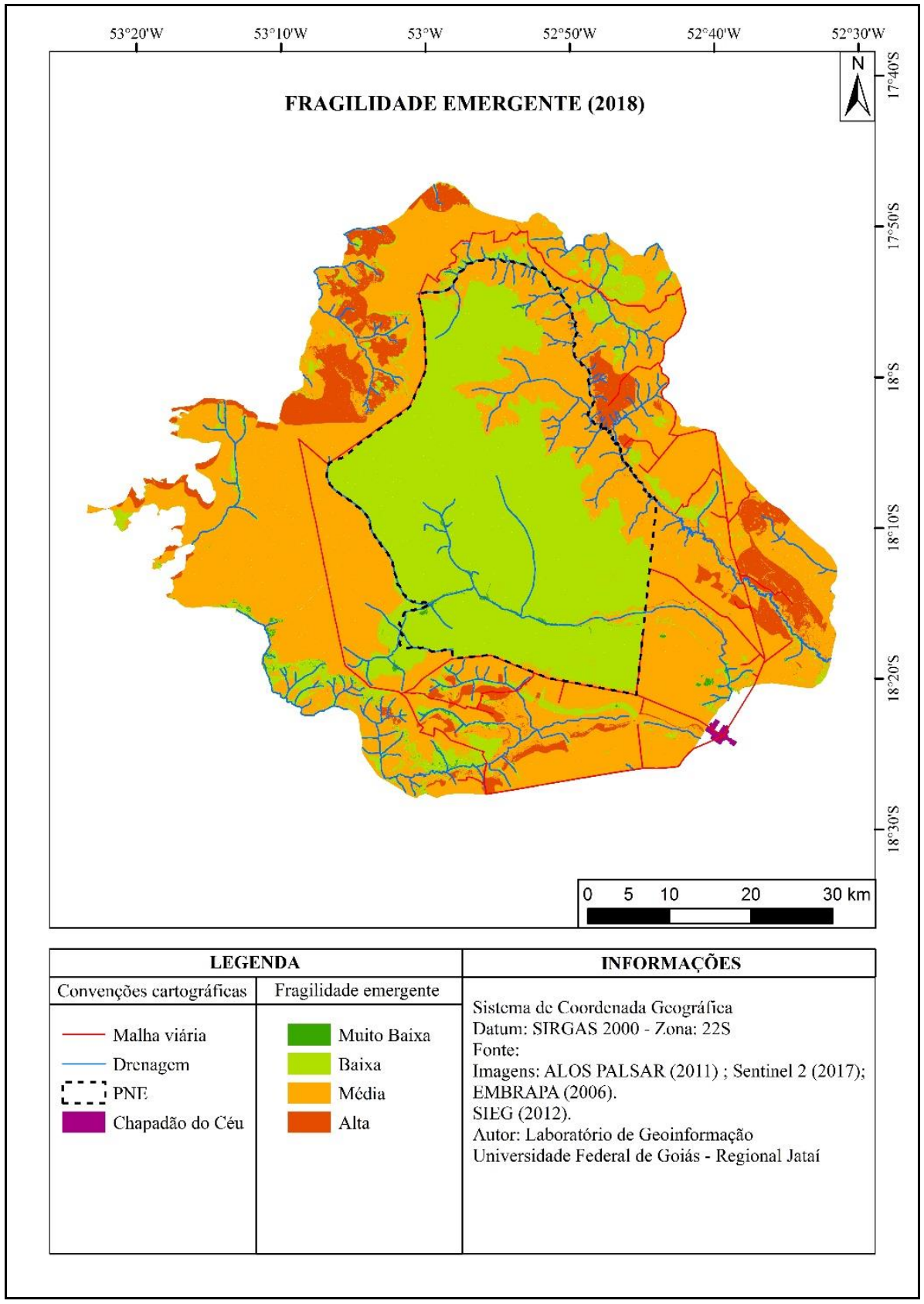

Fonte: Autores (2018)

As áreas com fragilidade potencial classificadas como média $(27,5 \%)$ coincidem com áreas de ocorrência de solos mais frágeis, como os neossolos quartzarênicos e litólicos e os gleissolos, visto que não existem grandes variações nas declividades do terreno. Nestas áreas, a utilização dos recursos naturais devem ser acompanhadas pela implementação de algumas técnicas conservacionistas de manejo dos solos, 
como o plantio em curvas de nível, a construção de caixas de contenção às margens das vias de circulação e a conservação das faixas de preservação permanente.

Apenas $0,9 \%$ da área é classificada como fragilidade alta, associadas principalmente a áreas com declividades mais acentuadas (encostas) e a solos com maiores níveis de fragilidade, como os neossolos e os gleissolos. Em uma visão conservacionista, entende-se que estas áreas não devem ser destinadas a atividades agropecuárias.

Para analisar a fragilidade emergente (fragilidade ambiental), é preciso considerar os graus de proteção que a categoria de uso e cobertura da terra conferem ao ambiente. Por exemplo, áreas intensamente ocupadas por atividades agrícolas promovem uma baixa proteção dos solos, enquanto que áreas com vegetação natural oferecem um alto grau de proteção. Essas questões explicam a predominância de áreas de fragilidade emergente classificadas como "media" em áreas que apresentam fragilidade potencial baixa. As áreas mapeadas com fragilidade média $(56,9 \%$ da área total) ocorrem em regiões intensamente ocupadas por atividades agropecuárias, especialmente cultivo de grãos e cana-de-açúcar, e áreas que mesmo com cobertura de vegetação natural, apresentam solos e relevo com níveis mais elevados de fragilidade.

As áreas classificadas com fragilidade muito baixa $(0,7 \%)$ e baixa $(34,7 \%)$ ocorrem predominantemente no interior do Parque Nacional das Emas e em áreas da Zona de Amortecimento que ainda apresentam fragmentos conservados de vegetação sobre solos mais estáveis. É exatamente essa vegetação natural conservada que confere níveis mais baixos de fragilidade a estes ambientes.

A classe Alta de fragilidade ocorre em $7,7 \%$ da área de estudo, especialmente sobre áreas de neossolos e geissolos ocupadas por atividades agropecuárias e com relevo suave ondulado. As manchas de alta fragilidade são mais significativas na região das nascentes do rio Araguaia, na bacia hidrográfica do Córrego Serrado, em áreas próximas às nascentes do rio Douradinho, margens do rio Jacuba e nascentes do rio Sucuriú. Nessas áreas as atividades agropecuárias devem ser restritas e apresentar diversas técnicas conservacionistas para manejo do ambiente visto a alta 
susceptibilidade de degradação, principalmente por erosão dos solos e assoreamento dos cursos d'água.

Conhecer as potencialidades e limitações do ambiente físico em uma região representa a base para o planejamento de uso das terras, visto que esse planejamento permite uma visão integrada e especializada sobre o ambiente explorado. Assim como os estudos de fragilidade ambiental, o mapeamento de capacidade de uso das terras (Figuras 14 e 15) permite a identificação de áreas mais fragilizadas, onde o uso dos recursos naturais em atividades agropecuárias deva ser restringido, visando a conservação do ambiente.

O mapa de capacidade de uso desenvolvido para a Zona de Amortecimento apresenta predomínio da classe A (terras passíveis de utilização com culturas anuais, perenes, pastagens, reflorestamento e conservação da vida silvestre, representadas pelas cores verdes), sendo que $70,2 \%$ da área encontra-se apta ao cultivo agrícola com problemas simples de conservação e 17,4\% encontra-se apta ao cultivo agrícola com problemas complexos de conservação, sobretudo correção de solos e criação de mecanismos para prevenção e/ou contenção de processos erosivos. Dessa forma, conclui-se que $87,6 \%$ da área da Zona de Amortecimento apresenta condições favoráveis ao desenvolvimento da agricultura, área superior à que encontra-se recoberta por este tipo de atividade atualmente. Esse resultado deve-se, principalmente, às características apresentadas pelos solos, pelo clima e pelo relevo da região e o cálculo exclui a área ocupada pelo PNE. Embora apresentem aptidão, sugere-se a elaboração de um plano de ocupação por parte da administração do Parque Nacional das Emas visando não isolar ainda mais a unidade de conservação, além da manutenção dos recursos hídricos e da biodiversidade.

Figura 14 - Capacidade de uso da terra (2018). 


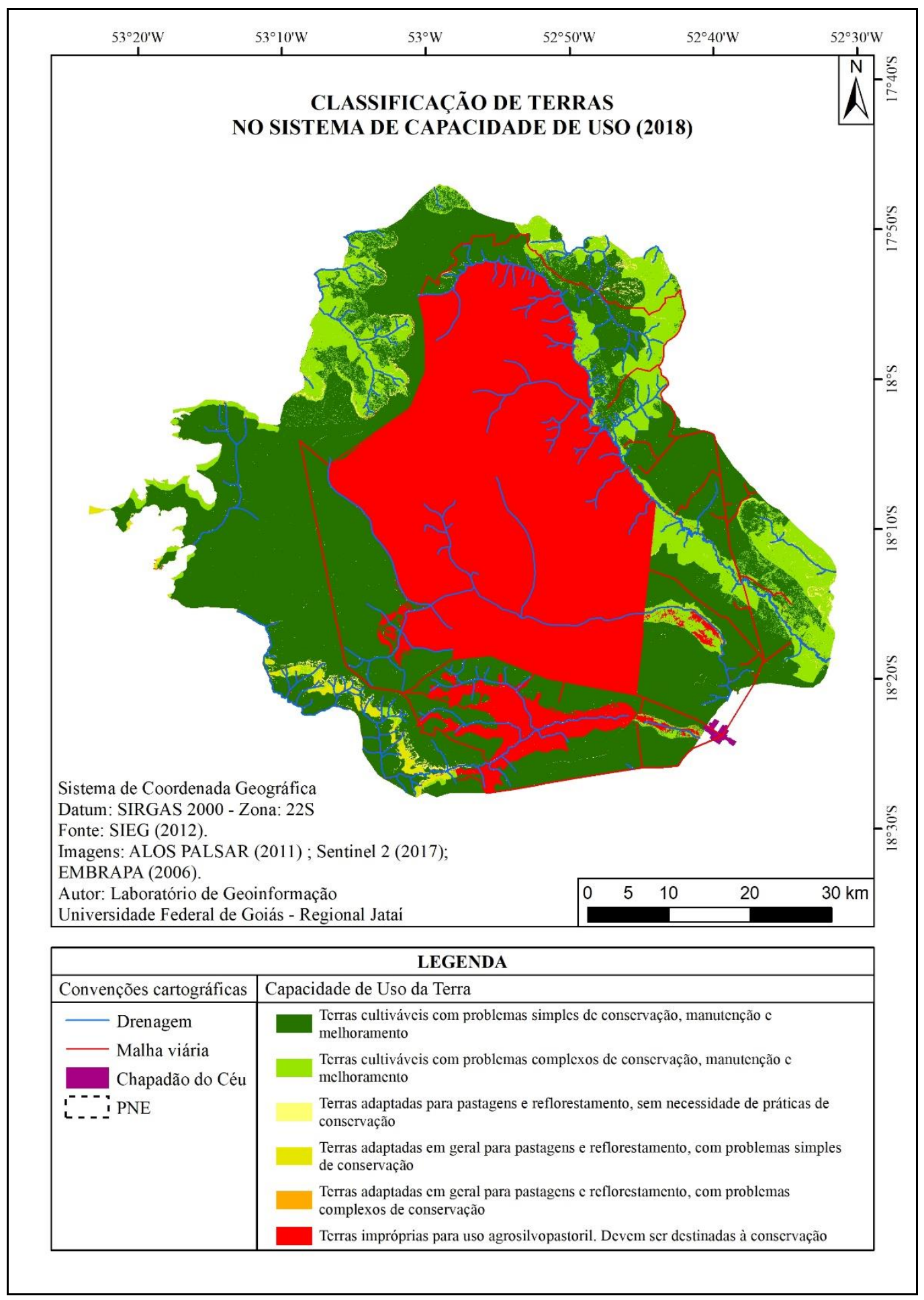

Fonte: Autores (2018) 
Figura 15 - Paisagens encontradas na Zona de Amortecimento do Parque Nacional das Emas, apresentando diferentes níveis de fragilidade e/ou capacidade de uso da terra.
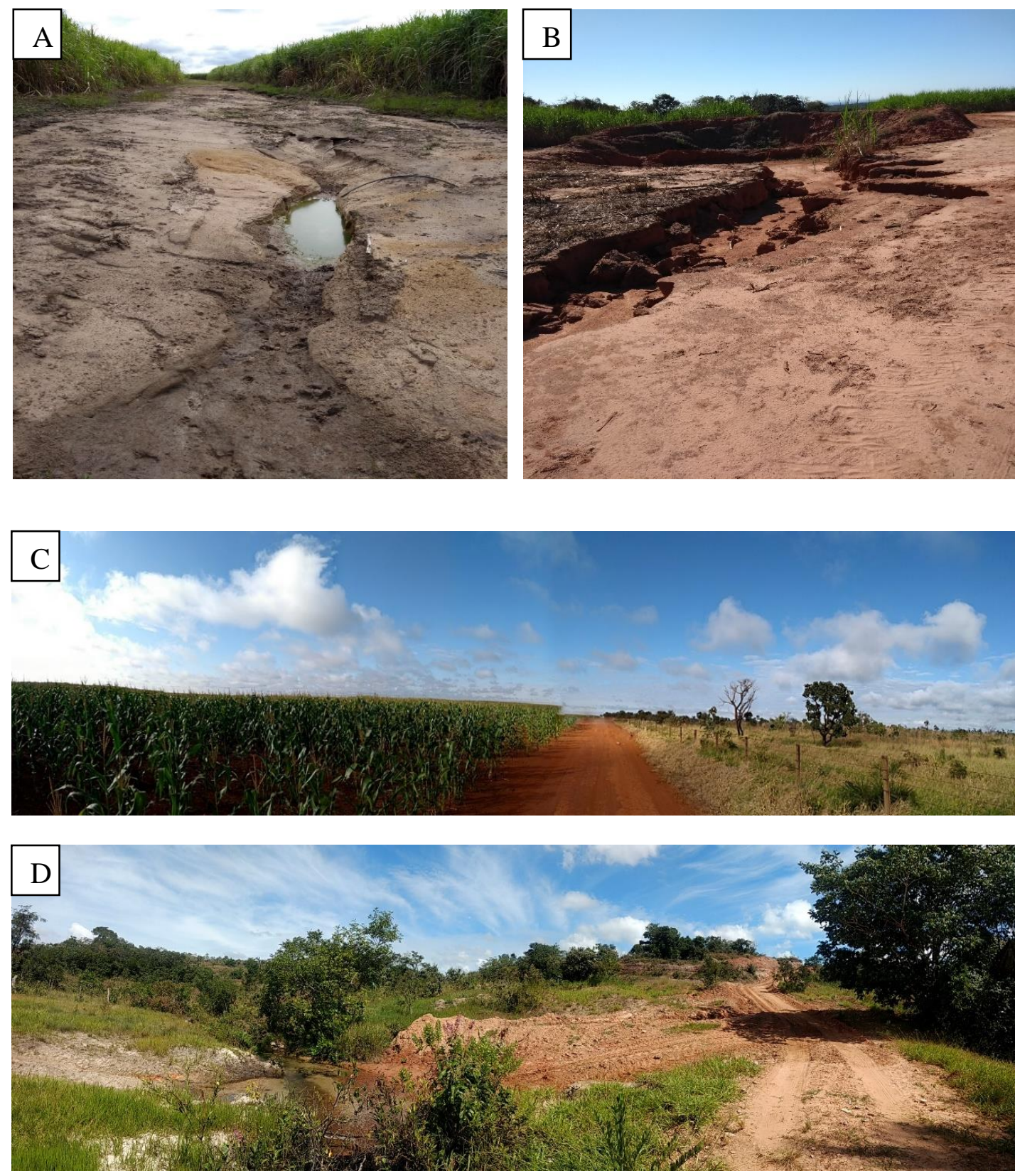

Fonte: Acervo particular dos autores (maio de 2018)

Legenda: A) Área cultivada com cana-de-açúcar sobre solos hidromórficos no município de Costa Rica (MS), com alta fragilidade ambiental. Observa-se um ponto de afloramento de água, além de um início de formação de ravina pela ação da água pluvial; B) Caixa de contenção construída às margens de estrada rural para evitar erosão em área cultivada com cana-de-açúcar em Neossolo Quartzarênico no município de Serranópolis (GO). É possível observar que, mesmo com a adoção de práticas conservacionistas, existe o risco de perda de solos por erosão (abertura de ravina evidente); C) Contato entre área de plantio de milho e o Parque Nacional das Emas no município de Chapadão do Céu (GO). Nota-se que além da estrada de aproximadamente 5 metros de largura, não existe faixa de aceiro no interior da unidade de conservação; D) Panorâmica da região do Córrego Faveiro no município de 
Serranópolis. A região apresenta alta fragilidade ambiental, solos muito arenosos, relevo ondulado, presença de alguns processos erosivos e manchas de vegetação natural ainda conservadas.

Quanto às áreas incluídas na classe $B$, adaptadas a pastagens e silvicultura em diferentes níveis de conservação, mas inaptas ao desenvolvimento da agricultura, têm-se um percentual de apenas $2,4 \%$ de área. Isto não impede que áreas enquadradas na classe A sejam destinadas a estas práticas.

As áreas impróprias (Classe C, em vermelho na figura 14) correspondem a 10,2\% da Zona de Amortecimento, sobretudo sobre gleissolos, neossolos, áreas úmidas e terrenos com declividades superiores a 30\% de inclinação. Destaca-se também toda a área do Parque Nacional das Emas, classificada como imprópria por ser uma Unidade de Conservação, não inserida no cálculo.

A partir da análise dos mapas de uso e cobertura da terra, fragilidade ambiental e capacidade de uso da área de estudo, foi desenvolvido um mapeamento (figura 16) com a finalidade de indicar áreas potenciais para a criação de Unidades de Conservação na Zona de Amortecimento e de estabelecer ligações entre o parque e outras áreas com vegetação natural conservada na região.

Para esta análise foram consideradas as seguintes variáveis: a) manchas com vegetação remanescente (feições de cerrado e floresta) com áreas superiores a 100 ha; b) Zona de 500 m no entorno do Parque Nacional das Emas; c) Faixa de $100 \mathrm{~m}$ a cada margem dos cursos d'água; d) Áreas úmidas; e) Declividade do terreno (inclinações superiores a 25\%).

Excluindo-se a área do Parque Nacional das Emas, que já é uma Unidade de Conservação consolidada, apenas $1,3 \%$ da área apresentou alto potencial para implantação de unidades de conservação, se restringindo às faixas de preservação permanente determinadas para os cursos d'água. Esse baixo percentual deve-se, principalmente, à intensa fragmentação vegetal da Zona de Amortecimento e indica a possibilidade de criação de corredores ecológicos nas faixas indicadas em vermelho na figura 16. 
Figura 16 - Estudo de viabilidade para alocação de Unidades de Conservação na Zona de Amortecimento do Parque Nacional das Emas.

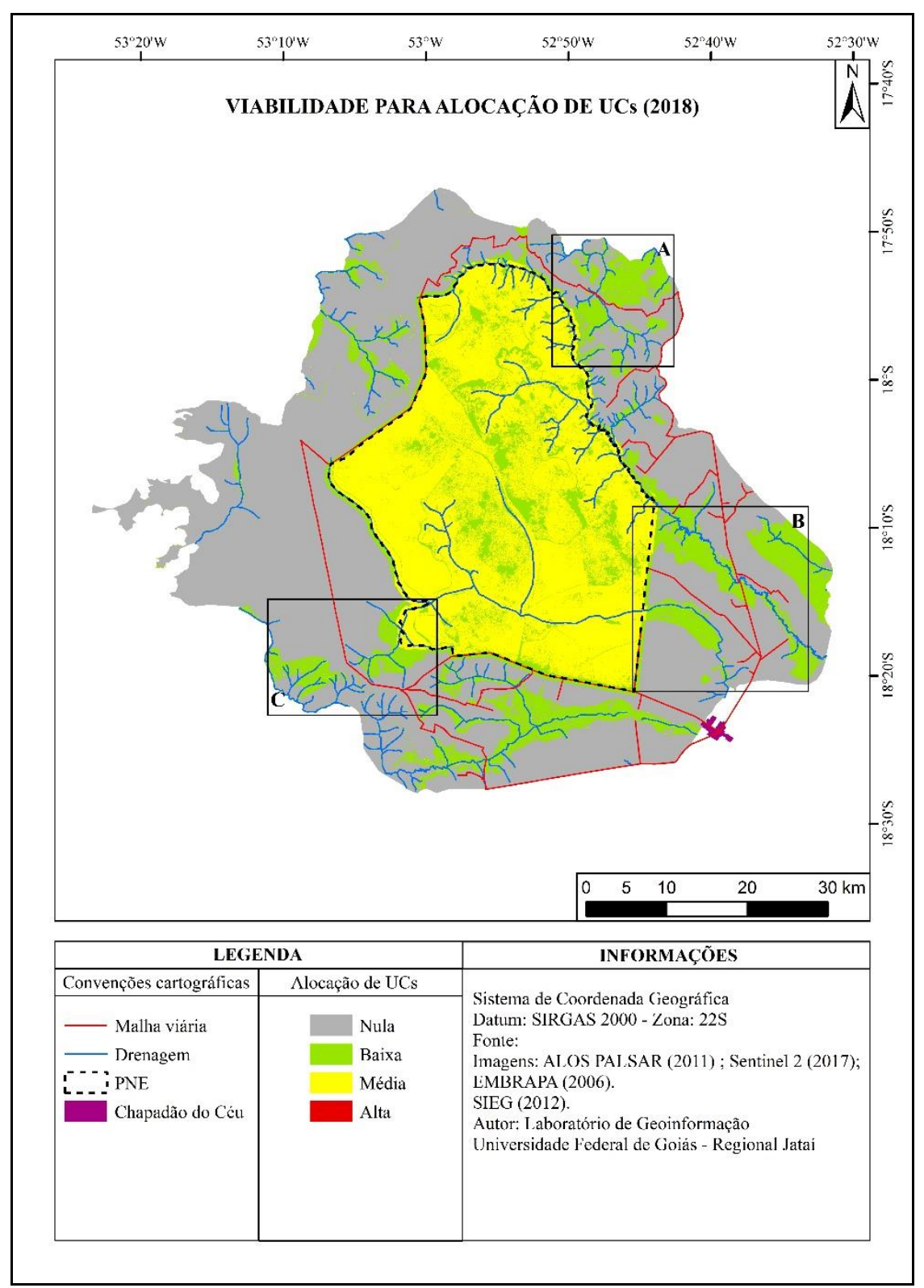

Fonte: Autores (2018)

A área com viabilidade média coincidiu com os limites do Parque Nacional das Emas e cabe destacar aqui diversas áreas classificadas como baixas $(18,6 \%$ da área total), mas que coincidem com os maiores fragmentos de vegetação natural conservados, podem servir como pontos de conexão entre o parque e áreas de 
nascentes e bacias hidrográficas do entorno (Figura 17 A, B e C). Juntos, estes fragmentos somam mais de 70.000ha que podem ser aproveitados para a conservação da biodiversidade local.

Figura 17 - Áreas indicadas como potenciais para alocação de Unidades de Conservação.

A

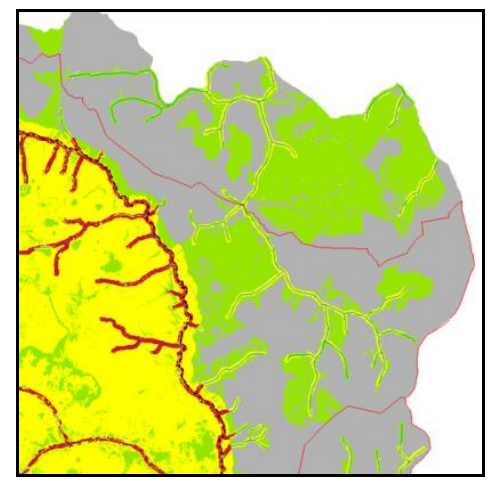

B

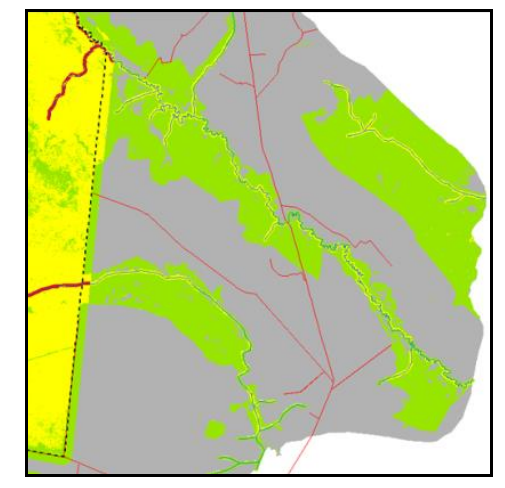

C

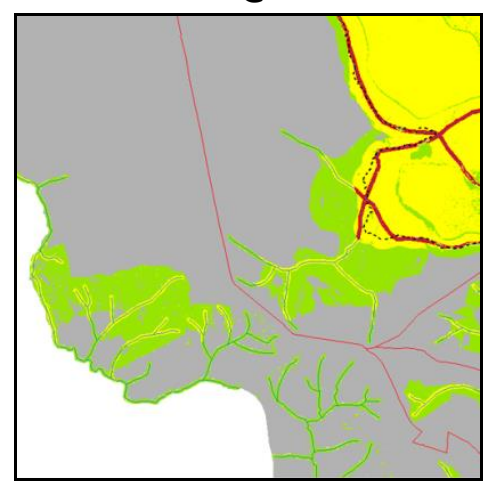

Fonte: Autores (2018)

O ponto indicado como A encontra-se entre os municípios de Serranópolis e Mineiros, apresenta relevo predominantemente ondulado, solos arenosos e diferentes feições de cerrado, em especial áreas de Cerradão que são pouco observadas na área do Parque Nacional das Emas. Além da proximidade com o parque, possibilita a conexão entre a Unidade de Conservação e a bacia do Rio Verde, importante afluente da margem direita do Rio Paranaíba, em conjunto com o Rio Corrente. A região apresenta algumas áreas de criação extensiva de gado, mas apresenta potencial para constituição de uma Área de Preservação Ambiental (APA), embora esteja distante das áreas ocupadas por plantios da Usina Cerradinho e mais próximo a áreas de cultivo no município de Mineiros, pertencentes a outra empresa do setor.

A segunda região identificada, representada pela letra B nas figuras 16 e 17, localiza-se entre os municípios de Chapadão do Céu e Serranópolis, às margens dos Rios Formoso e Jacuba e nascentes do Rio Douradinho. Pela intensa ocupação agrícola, não se mostra viável a criação de unidades de conservação, mas recomendase a criação de corredores ecológicos utilizando as faixas marginais dos cursos d’água, visto que estes apresentam consideráveis áreas de vegetação conservada, além de porções de áreas úmidas. Avaliando o ambiente de forma integrada e, 
considerando o plantio de cana-de-açúcar, seria a área mais favorável ao desenvolvimento de ações de compensação ambiental e conservação do ambiente.

A terceira área selecionada, indicada pela letra $C$, localiza-se em uma faixa de contato entre o Parque Nacional das Emas (nascentes do Rio Formoso) e afluentes da bacia do Rio Sucuriú, no Mato Groso do Sul. Além das áreas de remanescentes, a região apresenta porções significativas de áreas úmidas, cuja conservação é condição fundamental para a manutenção do sistema hídrico. Apesar da intensa ocupação agrícola, entende-se que seja viável a criação de unidades do tipo APA ou RPPN para a conservação deste conjunto de nascentes.

\section{CONSIDERAÇÕES FINAIS}

O conceito de paisagem, em si, permite diversas interpretações em áreas como a Zona de Amortecimento do Parque Nacional das Emas. Neste estudo e, a partir das análises realizadas em campo, com suporte na cartografia de síntese, conclui-se que:

a) O Parque Nacional das Emas apresenta-se hoje como uma "ilha de vegetação", não cumprindo totalmente sua função de conservação da biodiversidade e manutenção dos sistemas ambientais;

b) Embora cercado por atividades agropecuárias, o PNE encontra-se em uma área com potencialidades para a criação de corredores ecológicos e unidades de uso sustentável, que auxiliem em suas funções ambientais, minimizando os impactos das atividades desenvolvidas em sua Zona de Amortecimento. Cerca de $25 \%$ da Zona de Amortecimento encontra-se coberta por manchas de vegetação remanescente e áreas úmidas, com potencial para conservação;

c) A Zona de Amortecimento do Parque Nacional das Emas encontra-se intensamente ocupada por atividades agropecuárias, sobretudo pelo plantio de grãos, mas o ambiente apresenta níveis médios e baixos de fragilidade, indicando que é possível conciliar as atividades de produção com a conservação do ambiente;

d) As áreas úmidas constituem os principais pontos de conflito ambiental, apresentando áreas de cultivo em terrenos que deveriam ser destinados à 
conservação dos recursos hídricos, motivo pelo qual sugere-se um acompanhamento mais cuidadoso destas áreas. Deve-se ter atenção especial com as áreas de cultivo sobre neossolos quartzarênicos, que apresentam uma maior susceptibilidade natural à erosão.

\section{AGRADECIMENTOS}

Agradecemos a UFG/Regional Jataí pela disponibilização do espaço e equipamentos do Laboratório de Geoinformação da Unidade Acadêmica Especial de Estudos Geográficos para o desenvolvimento desta pesquisa. A Usina Cerradinho Bioenergia S.A. pelo apoio logístico e pela autorização de ingresso em áreas de plantio de cana-de-açúcar para realização das análises. E a Hidrocon Consultoria e Engenharia Ltda. pela parceria de trabalho por meio de convênio com a Universidade e pelo apoio financeiro no pagamento de bolsas de estudo e na viabilização das atividades de campo.

\section{REFERÊNCIAS}

ALVES, R. E. Caracterização da paisagem a partir da fragilidade ambiental da Bacia Hidrográfica do Ribeirão da Picada - Jataí/GO. 2012. 119 p. Dissertação (Mestrado em Geografia) - Universidade Federal de Goiás - Regional Jataí, Jataí-GO, 2012.

BERTRAND, G. Paisagem e Geografia Física global: esboço metodológico. Caderno de Ciências da Terra, São Paulo, n.13, p.2-27, 1972.

BRASIL. Lei n. 12,651, de 25 de maio 2012. Dispõe sobre a proteção da vegetação antiva. Disponível em: <http://www.planalto.gov.br/ccivil_03/_Ato2011-2014/2012/Lei/L12651.htm\#art83 >. Acesso em: 25 de maio de 2018.

BRASIL. Decreto n. 4.340, de 22 de agosto de 2002. Dispõe sobre o Sistema Nacional de Unidades de Conservação da Natureza - SNUC. Disponível em: < https://www.planalto.gov.br/ccivil_03/decreto/2002/d4340.htm>. Acesso em: 25 de maio de 2018.

BRASIL. Lei n. 9.985, de 18 de julho de 2000. Institui o Sistema Nacional de Unidades de Conservação da Natureza. Disponível em: https://www.planalto.gov.br/ccivil_03/LEIS/L9985.htm>. Acesso em: 25 de maio de 2018.

BRASIL. Lei n. 9.433, de 8 de Janeiro de 1997. Dispõe sobre a Política Nacional de Recursos Hídricos. Disponível em : < http://www.planalto.gov.br/ccivil_03/leis/L9433.htm>. Acesso em: 25 de maio de 2018. 
BRASIL. Lei n. 7.804, de 18 de junho de 1989. Altera a Política Nacional do Meio Ambiente. Disponível em: < http://www.planalto.gov.br/ccivil_03/leis/L7804.htm >. Acesso em: 25 de maio de 2018.

BRASIL. Constituição da República Federativa do Brasil. Brasília: Senado Federal,1988.

BRASIL. Lei n. 7.347, de 24 de julho de 1985. Disciplina a ação civil pública de responsabilidade por danos causados ao meio-ambiente, ao consumidor, a bens e direitos de valor artístico, estético, histórico, turístico e paisagístico (VETADO). Disponível em: https://www.planalto.gov.br/ccivil_03/LEIS/L7347orig.htm>. Acesso em: 25 de maio de 2018.

BRASIL. Lei n. 6.938, de 31 de agosto de 1981. Dispões sobre a Política Nacional do Meio Ambiente. Disponível em: < http://www.planalto.gov.br/ccivil_03/LEIS/L6938.htm>. Acesso em: Acesso em: 25 de maio de 2018.

BRASIL. Lei n. 4.771, de 15 de setembro de 1965. Institui o Novo Código Florestal. Disponível em: < http://www.planalto.gov.br/ccivil_03/leis/L4771.htm>. Acesso em: 25 de maio de 2018.

CABRAL, N. R. A. J.; SOUZA, M. P. Área de proteção ambiental: planejamento e gestão de paisagens protegidas. 2 ed. São Carlos: RiMa, 2005.

CREPANI, E. et al. Sensoriamento remoto e geoprocessamento aplicados ao zoneamento ecológico-econômico e ao ordenamento territorial. São José dos Campos: INPE, 2001.

ESRI - Environmental Systems Research Institute Inc. ArcGis versão 10.1. EUA: Environmental Systems Research Institute, 2012.

GOIÁS. Lei n. 14.247, de 29 de julho de 2002. Institui o Sistema Estadual de Unidades de Conservação no Estado de Goiás. Disponível em: < http://www.gabinetecivil.goias.gov.br/leis_ordinarias/2002/lei_14247.htm>. Acesso em: 25 de maio de 2018.

GUERRA, A. J. T. et al. Um estudo do meio físico com fins de aplicação ao planejamento do uso agrícola da terra no Sudoeste de Goiás. Rio de Janeiro: IBGE, 1989.

HANNAFORD, M.J., BARBOUR, M.T., RESH, V.H. Training Reduces Observer Variability In VisualBased Assessments Of Stream Habitat. Journal Of The North American Benthological Society, v. 16, n. 4, p. 853-860, 1997.

IBGE - INSTITUTO BRASILEIRO DE GEOGRAFIA E ESTATístiCA. Censo Demográfico de 2010. [2010]. Disponível em: <www.ibge.gov.br>. Acesso em: 25 de maio de 2018.

IBGE - INSTITUtO bRASILEIRO DE GEOGRAFIA E eSTAtístiCA. Manual técnico de Pedologia. Rio de Janeiro: IBGE, 2015.

IBGE - INSTITUTO BRASILEIRO DE GEOGRAFIA E ESTATÍSTICA. Manual técnico de uso da Terra. Rio de Janeiro: IBGE, 2013.

IBGE - INSTITUTO BRASILEIRO DE GEOGRAFIA E ESTATÍ́STICA. Manual técnico de Geomorfologia. Rio de Janeiro: IBGE, 2009.

INMET - INSTITUTO NACIONAL DE METEOROLOGIA. BDMEP. Disponível em: <http://www.inmet.gov.br/portal/index.php?r=bdmep/bdmep>. Acesso em: 15 maio 2018.

KAWAKUBO, F. S. et al. Caracterização empírica da fragilidade ambiental utilizando geoprocessamento. In: SIMPÓSIO BRASILEIRO DE SENSORIAMENTO REMOTO, 12, 2005, Goiânia. Anais[...] Goiânia: Instituto de Pesquisas Espaciais, 2005. p. 16-21. 
LEPSCH, I. F. Manual para levantamento utilitário do meio físico e classificação de terras no sistema de capacidade de uso. 2 ed. Campinas: Sociedade Brasileira de Ciência do Solo, 1991.

MATSUMOTO, M. et al. LegalGeo: Um aplicativo pra a identificação das áreas potenciais para recuperação e implementação de reservas legais no cerrado. In: PAESE, A. et al. (Org.) Conservação da Biodiversidade com SIG. São Paulo: Oficina de Textos, 2012.

MMA - MINISTÉRIO DO MEIO AMBIENTE. Plano de manejo do Parque Nacional das Emas. Disponível em: <http://observatorio.wwf.org.br/site_media/upload/gestao/planoManejo/PM_parna_emas.pd> Acesso em 15 mar. 2018.

ROSS, J. L. S. Análise empírica da fragilidade dos ambientes naturais e antropizados. Revista do Departamento de Geografia da USP, São Paulo, SP. n. 8, p. 63-74, fev. 1993. Disponível em: <http://www.revistas.usp.br/rdg/article/view/47327/51063>. Acesso em 10 jun. 2018.

SANTOS, P. T. Planejamento ambiental de unidades de conservação: estudo de caso na bacia hidrográfica do Rio Claro - Goiás. 2018. 152 p. Dissertação (Mestrado em Geografia) - Universidade Federal de Goiás - Regional Jataí, Jataí-GO, 2018.

SIEG - SISTEMA ESTADUAL DE ESTATÍSTICA E INFORMAÇÕES GEOGRÁFICAS DE GOIÁS. Base cartográfica e Mapas temáticos do Estado de Goiás. Disponível em: <http://www.sieg.go.gov.br/>. Acesso em: 25 mar. de 2018.

SPÖRL, C.; ROSS, J. L. S. Análise comparativa da fragilidade ambiental com aplicação de três modelos. Revista Geousp -Espaço e Tempo, São Paulo, SP. n.15, p.39-49, 2004.

TUCCI, C. E. M.; MENDES, C. A. Avaliação ambiental integrada de bacia hidrográfica. Brasília: MMA, 2006.

UNITED STATES GEOLOGICAL SURVEY (USGS). Downloads de imagens Sentinel2. Disponível em: <https://earthexplorer.usgs.gov/>. Acesso em: Acesso em: 25 de mar. de 2018.

VITALLI, P. L.; ZAKIA, M. J. B.; DURIGAN, G. Considerações sobre a legislação correlata à zonatampão de unidades de conservação no Brasil. Ambiente \& Sociedade, v.12, n.1, p.67-82, jan./jun. 2009. 